\title{
Composition and Antimicrobial Activity of Essential Oils from Poiretia bahiana C. Müller (Papilionoideae-Leguminosae)
}

\author{
Floricéa M. Araújo, ${ }^{a}$ Maria das Graças V. M. Passos, ${ }^{b}$ Edeltrudes de O. Lima,${ }^{c}$ Nídia F. Roque, ${ }^{a}$ \\ Maria L. S. Guedes, ${ }^{d}$ Lourdes C. de Souza-Neta, ${ }^{a}$ Frederico Guaré Cruz ${ }^{* a}$ and Dirceu Martins ${ }^{a}$
}

\author{
${ }^{a}$ Instituto de Química, ${ }^{b}$ Faculdade de Farmácia and ${ }^{d}$ Instituto de Biologia, \\ Universidade Federal da Bahia, Campus de Ondina, 40190-270 Salvador-BA, Brazil
}

${ }^{c}$ Centro de Ciências da Saúde, Universidade Federal da Paraíba, 58059-900 João Pessoa-PB, Brazil

A espécie Poiretia bahiana, popularmente conhecida como arrudinha, arruda da serra ou arruda brava, tem uma ocorrência restrita aos campos rupestres da Chapada Diamantina, BA. Suas partes aéreas apresentam um aroma pungente e é usada pelo povo do local no controle de infestações por pulgas e no tratamento de hemorróidas, dores nas articulações e sinusite. Neste trabalho, relatamos a composição dos óleos voláteis obtidos das partes aéreas de cinco espécimes e do óleo volátil obtido dos frutos de um espécime de $P$. bahiana, os quais foram coletados em diferentes regiões da Chapada Diamantina. Nos óleos voláteis que foram analisados por CG-FID e CG-EM foram identificados vinte e nove componentes sendo que os dois principais foram a umbelulona, em concentrações entre 55,0\% e 75,3\%, e sabineno, em concentrações entre 10,3\% e $25,2 \%$. O óleo das partes aéreas de um espécime e o óleo dos frutos de outro espécime foram avaliados quanto às suas propriedades antimicrobianas contra seis bactérias, duas leveduras e cinco fungos filamentosos pelos ensaios de difusão em ágar e microdiluição. Os óleos exibiram atividade contra Escherichia coli, Salmonella choleraesuis, Proteus mirabilis, Staphylococcus aureus, Staphylococcus aureus resistente à meticilina (MRSA), Candida albicans, Cryptococcus neoformans, Cladosporium herbarum, Microsporum canis, Trichophyton rubrum e foram inativos contra Pseudomonas aeruginosa, Aspergillus fumigatus e Penicillium notatum. A toxicidade do óleo das partes aéreas foi determinada contra Artemia salina apresentando uma $\mathrm{LC}_{50}$ de $459,03 \mu \mathrm{g} \mathrm{mL}^{-1}$.

Poiretia bahiana known as "arrudinha", "arruda da serra" or "arruda brava", has its occurrence restricted to the rock fields (campo rupestre) areas in Chapada Diamantina, Bahia, northeastern region of Brazil. Its aerial parts present a pungent smell and have been used by local communities as fumigant for the control of infestation of fleas and in the treatment of hemorrhoids, articulations pain and sinusitis. This work reports the composition of the volatile oils from aerial parts of five specimens and of the essential oil from the fruits of one specimen of Poiretia bahiana that were harvested in four different places of Chapada Diamantina. Twenty nine components were identified from the oils analyzed by GC-FID and GC-MS. Umbellulone, in concentrations between $55.0 \%$ and $75.3 \%$ and sabinene, in concentrations between $10.3 \%$ and $25.2 \%$ are the major components. The oil from the aerial parts of one specimen and the oil of fruits of another specimen had their antimicrobial properties evaluated against six bacteria, two yeasts and five filamentous fungi by the agar diffusion method and microdilution assay. The in vitro results demonstrated that these essential oils exhibit antimicrobial activity against Escherichia coli, Salmonella choleraesuis, Proteus mirabilis, Staphylococcus aureus, methicilin resistant Staphylococcus aureus (MRSA), Candida albicans, Cryptococcus neoformans, Cladosporium herbarum, Microsporum canis, Trichophyton rubrum and are inactive against Pseudomonas aeruginosa, Aspergillus fumigatus and Penicillium notatum. The oil obtained from the aerial parts of one specimen displayed moderate toxicity against Artemia salina with a $\mathrm{LC}_{50}$ value of $459.03 \mu \mathrm{g} \mathrm{mL} \mathrm{L}^{-1}$.

Keywords: Poiretia bahiana, essential oil, umbellulone, sabinene, antimicrobial activity

*e-mail: fguare@ufba.br 


\section{Introduction}

The genus Poiretia comprises 12 species that are widespread in the tropical and subtropical America from México and Antilhas to Argentina. ${ }^{1}$ In Brazil, the people use some species with therapeutic purposes. Thus, P. tetraphylla is used as stomachal tonic, P. latifolia is used to input aroma for tea and it is considered as an aphrodisiac, and another Poiretia species is used in the state of Mato Grosso as anti-emetic against fever and meningitis. ${ }^{1}$ P. bahiana was first reported in $1984^{1}$ and its occurrence is restricted to the rock fields (campo rupestre) areas in Chapada Diamantina, Bahia, northeastern region of Brazil. The aerial parts of $P$. bahiana, known as "arrudinha", "arruda da serra" or "arruda brava", present a pungent smell and have been used by local communities as fumigant to kill fleas, in the treatment of hemorrhoids, articulation pain and as nasal decongestant in sinusitis. ${ }^{2}$ In the treatment of sinusitis the plant is used by inhalation of the vapors released in boiled water and it is possible that, besides a decongestant action, there is also an antimicrobial action against bacteria and fungi generally associated to sinusitis. As a fumigant to kill fleas, the aerial parts of the plant are dispersed by the infested places.

The aim of this work is the study of the composition of the volatile oils from aerial parts of five specimens and of the volatile oil from fruits of one specimen of $P$. bahiana, in addition to the evaluation of the antimicrobial properties of the oil from two specimens against six bacteria, two yeasts and five filamentous fungi and of the toxicity of the oil from the aerial parts against Artemia salina. The specimens were harvested in four different places of Chapada Diamantina named Morro do Pai Inácio, Mucugê, Morro do Chapéu and Chapadinha.

\section{Experimental}

\section{Plant material}

The aerial parts of three specimens of $P$. bahiana were collected in July 2004 in Morro do Pai Inácio (MPIFl), Mucugê $(\mathrm{MFl})$ and Chapadinha $(\mathrm{CFl})$ when the plants were flowering. The fruits were collected from the specimen found in Chapadinha (CFr). In September 2004, when the plants presented no flowers, the aerial parts of two specimens were collected in Mucugê (MWFI) and Morro do Chapéu (MCWFl). The species were identified by Prof. Maria Lenise da Silva Guedes and voucher specimens were deposited in the herbarium Alexandre Leal Costa at Instituto de Biologia, UFBA, under the numbers 032231, 032232,
032233, 032244 and 032245, respectively for MPIFl, MFl, $\mathrm{CFl}, \mathrm{MWFl}$ and $\mathrm{MCWFl}$.

\section{Essential oils analysis}

The aerial parts and fruits were dried on air at room temperature and reduced into small pieces. The volatile oils were obtained by $3 \mathrm{~h}$ hydrodistillation in a Clevenger-type apparatus. The identification of compounds was performed by comparison of their retention indices and mass spectra with those reported in the literature ${ }^{3,4}$ and stored in the NIST libraries (Mass Spectral Library, 1998). The retention indices were calculated by co-injection with a standard saturated $n$-alkanes homologous series.

GC analyses were performed as described previously. ${ }^{5}$

\section{Microbial strains}

Thirteen microbial strains were used to access the antimicrobial properties of the test samples: six bacteria, two yeasts and five filamentous fungi. Microorganisms were obtained from the culture collections of Instituto Nacional de Controle de Qualidade em Saúde- INCQS/ Brasil as follows: Escherichia coli ATCC 25922, Salmonella choleraesuis ATCC 10708, Pseudomonas aeruginosa ATCC 27853, Proteus mirabilis ATCC 29906, Staphylococcus aureus ATCC 25923, methicillin-resistant Staphylococcus aureus (MRSA) ATCC 33591, Candida albicans ATCC 90028, Cryptococcus neoformans ATCC 32045, Aspergillus fumigatus ATCC 16913, Cladosporium herbarum ATCC 26362, Microsporum canis ATCC32903, Penicillium notatum ATCC 9478 and Trichophyton rubrum ATCC 28189. Bacteria were grown on Mueller Hinton Agar (MHA) and fungi on Sabouraud Dextrose Agar (SDA) (Difco Laboratoires). Inocula were prepared as described previously. ${ }^{5}$

\section{Essential oils dilution}

The essential oils were tested pure and at dilutions ranging from $8 \%\left(72.5 \mathrm{mg} \mathrm{mL}^{-1}\right)$ to $0.25 \%\left(2.3 \mathrm{mg} \mathrm{mL}^{-1}\right)$ for agar diffusion method and for the determination of Minimum Inhibitory Concentration by microdilution assays. The dilutions were prepared in sterile distilled water with addition of Tween 80 (Merck) to the first dilution in a concentration of $10 \%(\mathrm{v} / \mathrm{v})$, each dilution being mixed on Vortex apparatus. ${ }^{6}$ Due to the similarity of the oils composition, only the oils from the aerial parts collected in Morro do Pai Inácio (MPIFl) and from the fruits collected in Chapadinha (CFr) in July 2004 had their antimicrobial properties and toxicity tested. 


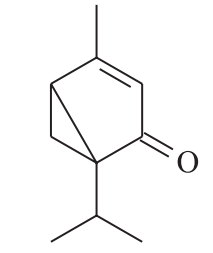

umbellulone

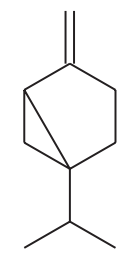

sabinene
Figure 1. Chemical structure of umbellulone and sabinene.

\section{Agar diffusion method}

To evaluate antimicrobial activity, assays were performed in duplicate as described previously. ${ }^{5}$ The bioassay results (Table 2) were expressed in terms of mean of inhibition zone diameters: $<9 \mathrm{~mm}$, inactive; $9-12 \mathrm{~mm}$, partially active; $12-18 \mathrm{~mm}$, active; $>18 \mathrm{~mm}$, very active. ${ }^{7}$

\section{Minimum Inhibitory Concentration (MIC)}

MIC assays were performed by Broth Microdilution Method as described previously. ${ }^{5}$

\section{Toxicity against Artemia salina}

The brine shrimp lethality assay was performed by the method of McLaughlin and co-workers. ${ }^{8}$ Brine shrimp eggs (Artemia salina) were hatched in saline solution of $\mathrm{NaCl}$ $\left(38 \mathrm{~g} \mathrm{~L}^{-1}\right)$. The essential oil was tested at concentrations of 300,500 and $1000 \mu \mathrm{g} \mathrm{L}-1$. Survival was measured after $24 \mathrm{~h}$ incubation at $10{ }^{\circ} \mathrm{C}$. The collected data were computerized and $\mathrm{LC}_{50}$ values determined by Probit analysis.

\section{Results and Discussion}

Twenty-nine compounds were identified in the essential oils from aerial parts and fruits of $P$. bahiana (Table 1). Umbellulone is the major constituent in the essential oils from the aerial parts of all specimens of $P$. bahiana with flowers or without flowers, with a mean concentration of $60.6 \%$. The next most concentrated component was sabinene, with a mean concentration of $16.0 \%$. The essential oil from fruits showed umbellulone (58.2\%) and sabinene $(25.2 \%)$ as predominant compounds too. In addition to umbellulone and sabinene, myrcene, with a mean concentration $2.5 \%$, Z-ocimene, with a mean concentration $3.3 \%$, and germacrene $\mathrm{D}$, with a mean concentration $3.7 \%$, were presented in all samples analyzed. A complete study of seasonal variation in oil composition was not carried out, although in a general way, the oils collected in different geographical areas in July and September demonstrated high monoterpene content, specially oxygenated ones and variations in concentrations of the main components could be noted. Thus, the MPIFl sample, collected in July, was considerably richer in umbellulone content $(75 \%)$ than the other samples collected. The MFl and CFl samples, harvested in July, presented the highest content in sabinene among the aerial parts samples; however, the highest concentration of sabinene was found in the fuits (25.2\%). The essential oils from the flowery specimens presented larger yield of oil than those from the specimens without flowers; however, the best yield was presented by the essential oil from the fruits.

The assays with agar diffusion method revealed that the pure oils presented activity to most of the microorganisms tested except to $P$. aeruginosa, A. fumigatus and $P$. notatum (Table 2). The results of diluted oils showed that with regard to Gram-negative bacteria, only the oil from aerial parts presented partial activity to $E$. coli and the oil from fruits presented partial activity to $P$. mirabilis, both at $8 \%$ dilution. With regard to Gram-positive bacteria, the oil from aerial parts was active against MRSA and partially active against S. aureus at $8 \%$ while the oil from fruits presented partial activity to MRSA and was inactive against S. aureus at $8 \%$ dilution. The oil from aerial parts presented good activity while the oil from fruits presented partial activity to $C$. albicans at $8 \%$. Both oils showed activity to C. neoformans although the oil from aerial parts presented inhibition until $2 \%$ dilution with greater zones than those of the oil from fruits. Both oils showed to be partially active to the phytopathogenic specie $C$. herbarum at $8 \%$ dilution. The greatest inhibition zones were presented by both oils against M. canis although the oil from aerial parts showed good activity until $2 \%$ and the oil from fruits until $4 \%$ dilution. The oil from aerial parts presented good activity until $2 \%$ and the oil from fruits until $4 \%$ dilution to T. rubrum.

The minimum inhibitory concentrations of the essential oil obtained from the aerial parts were determined against six microbial species (Table 3 ). The results indicated that the oil presents strong activity against $C$. neoformans, $C$. albicans and $E$. coli with MIC values of 2.3, 2.3 and $9.1 \mathrm{mg} \mathrm{mL}^{-1}$, respectively and weaker activity against $P$. mirabilis, $S$. aureus and methicilin resistant $S$. aureus. Although agar diffusion and broth microdilution are commonly used methods to evaluate antimicrobial activity, the results obtained from each of these methods may differ as many factors vary between assays, which include differences in microbial growth, exposure of microorganisms to plant oils, the solubility of oils or oil components, the use and quantity of emulsifier and other elements. ${ }^{6,9,10}$ It is well known that agar diffusion method has its accuracy impaired as the hydrophobic nature of most essential oils prevents 
Table 1. Volatile compounds of the essential oils from Poiretia bahiana

\begin{tabular}{|c|c|c|c|c|c|c|c|}
\hline Compound & $\mathrm{KI}$ & MPIFl & MFl & $\mathrm{CFl}$ & MWFl & MCWFl & $\mathrm{CFr}$ \\
\hline$\alpha$-thujene & 930 & - & 0.5 & - & 0.3 & 0.4 & - \\
\hline$\alpha$-pinene & 938 & - & 0.7 & 0.7 & 0.5 & 0.4 & - \\
\hline thuja-2,4(10)-diene & 948 & - & 0.4 & - & 0.2 & 0.3 & - \\
\hline sabinene & 977 & 10.3 & 17.6 & 19.4 & 11.6 & 11.8 & 25.2 \\
\hline$\beta$-pinene & 980 & 0.7 & 1.8 & 1.6 & - & 1.3 & 1.8 \\
\hline myrcene & 992 & 1.3 & 2.9 & 2.8 & 2.2 & 2.8 & 3.1 \\
\hline$\alpha$-terpinene & 1019 & - & 0.9 & 0.8 & 0.8 & 1.3 & 1.1 \\
\hline o-ocimene & 1028 & - & - & - & - & 0.1 & - \\
\hline limonene & 1032 & 0.9 & 2.0 & 1.9 & 1.7 & 1.6 & - \\
\hline Z-ocimene & 1040 & 3.0 & 3.9 & 3.6 & 3.0 & 3.3 & 3.0 \\
\hline$E$-ocimene & 1051 & 1.3 & 0.9 & 0.8 & 2.0 & 2.6 & - \\
\hline$\gamma$-terpinene & 1062 & - & 1.4 & 1.3 & 1.2 & 2.1 & 1.8 \\
\hline cis-hydrate sabinene & 1070 & - & - & - & 0.3 & 0.2 & - \\
\hline terpinolene & 1090 & - & - & - & 0.3 & 0.5 & - \\
\hline linalool & 1101 & - & - & - & 0.8 & 1.0 & - \\
\hline thujone & 1118 & 1.3 & 1.4 & 1.3 & 1.4 & 1.6 & - \\
\hline p-menth-2-en-1-ol & 1123 & - & - & - & 0.3 & 0.4 & - \\
\hline umbellulone & 1177 & 75.3 & 55.0 & 58.3 & 60.4 & 56.4 & 58.2 \\
\hline terpinen-4-ol & 1179 & 1.7 & 2.9 & 3.1 & - & - & 4.0 \\
\hline$\alpha$-terpineol & 1191 & - & 0.6 & - & 0.7 & 0.9 & - \\
\hline methyl salicylate & 1195 & - & - & - & 0.5 & 0.4 & - \\
\hline thymol & 1294 & - & - & - & 1.6 & 1.9 & - \\
\hline E-caryophyllene & 1417 & 1.3 & 0.7 & - & 1.9 & 1.0 & - \\
\hline allo-aromadendrene & 1459 & - & - & - & 0.3 & 0.3 & - \\
\hline germacrene D & 1480 & 2.9 & 4.6 & 4.4 & 4.3 & 4.0 & 1.8 \\
\hline bicyclogermacrene & 1494 & - & 1.0 & - & 0.9 & 0.9 & - \\
\hline$\delta$-cadinene & 1522 & - & - & - & 0.2 & - & - \\
\hline spathulenol & 1576 & - & - & - & 0.5 & 0.4 & - \\
\hline caryophyllene oxide & 1580 & - & - & - & 0.6 & - & - \\
\hline Total & & 100.0 & 99.2 & 100.0 & 98.5 & 97.9 & 100.0 \\
\hline monoterpene hydrocarbons & & 17.5 & 33.0 & 32.9 & 23.8 & 28.5 & 36.0 \\
\hline oxygenated monoterpenes & & 78.3 & 59.9 & 62.7 & 63.9 & 60.5 & 62.2 \\
\hline sesquiterpene hydrocarbons & & 4.2 & 6.3 & 4.4 & 7.6 & 6.2 & 1.8 \\
\hline oxygenated sesquiterpenes & & - & - & - & 1.1 & 0.4 & - \\
\hline Others & & - & - & - & 2.1 & 2.3 & - \\
\hline yield / $(\%, \mathrm{~m} / \mathrm{m})$ & & 1.4 & 0.8 & 1.4 & 0.7 & 0.4 & 2.1 \\
\hline mass of dry material / $\mathrm{g}$ & & 124.0 & 148.0 & 150.0 & 119.0 & 139.0 & 61.0 \\
\hline
\end{tabular}

MPIFl: Morro do Pai Inácio with flowers; MFl: Mucugê with flowers; CFl: Chapadinha with flowers; MWFl: Mucugê without flowers; MCWFl: Morro do Chapéu without flowers; CFr: Chapadinha fruits.

the uniform diffusion of these substances through the agar medium that may account for differences on the obtained results.

These in vitro results demonstrated that essential oils from $P$. bahiana exhibit antimicrobial activity against E. coli, P. mirabilis, Staphylococcus species, yeasts and filamentous fungi, presenting greater inhibition zones to fungi than to bacteria. The oil obtained from aerial parts was shown to be more active than the one obtained from fruits due to quantitative and qualitative differences in their constituents, mainly in the content of umbellulone.
Probably, the biological properties of $P$. bahiana oils are associated to their high monoterpene content, specially umbellulone and sabinene, their major components. The strong activity depicted by the essential oils against $M$. canis and T. rubrum, the most common causative agent of dermatophytoses (onychomycosis, tinea or ringworm) worldwide infecting the hair, skin, and nails of patients with diabetes, peripheral vascular diseases or immunosupressed individuals ${ }^{12}$ suggests that they have a potential use as an alternative or complementary method to combat these microorganisms. Nevertheless, the literature reports that 
Table 2. Mean zones of growth inhibition (mm) showing antimicrobial activities of aerial parts (AP) and fruits (Fr) essential oil from Poiretia bahiana collected in July 2004

\begin{tabular}{|c|c|c|c|c|c|c|c|c|c|c|c|c|c|c|}
\hline \multirow[t]{3}{*}{ Microrganism } & \multirow{2}{*}{\multicolumn{2}{|c|}{ Pure Oil }} & \multicolumn{8}{|c|}{ Sample Concentration $(\mathrm{v} / \mathrm{v})$} & \multirow{3}{*}{$\begin{array}{c}\mathrm{GE} \\
10 \mu \mathrm{g}\end{array}$} & \multirow{3}{*}{$\begin{array}{l}\mathrm{OX} \\
1 \mu \mathrm{g}\end{array}$} & \multirow{3}{*}{$\begin{array}{c}\text { VA } \\
30 \mu \mathrm{g}\end{array}$} & \multirow{3}{*}{$\begin{array}{c}\mathrm{KT} \\
50 \mu \mathrm{g}\end{array}$} \\
\hline & & & \multicolumn{2}{|c|}{$8 \%$} & \multicolumn{2}{|c|}{$4 \%$} & \multicolumn{2}{|c|}{$2 \%$} & \multicolumn{2}{|c|}{$1 \%$} & & & & \\
\hline & AP & $\mathrm{Fr}$ & $\mathrm{AP}$ & $\mathrm{Fr}$ & AP & $\mathrm{Fr}$ & AP & $\mathrm{Fr}$ & AP & $\mathrm{Fr}$ & & & & \\
\hline E. coli & 14.0 & 11.5 & 9.2 & 8.8 & 8.5 & 8.2 & NI & NI & NI & NI & 15.0 & & & \\
\hline S. choleraesuis & 11.0 & 10.0 & 8.8 & NI & 8.0 & NI & $\mathrm{NI}$ & NI & NI & NI & 16.0 & & & \\
\hline P. mirabilis & 12.0 & 11.0 & 8.8 & 9.0 & 8.5 & 8.2 & NI & NI & NI & NI & 20.0 & & & \\
\hline S. aureus & 12.0 & 10.0 & 10.0 & 8.2 & 9.5 & NI & NI & NI & NI & NI & & 17.0 & & \\
\hline MRSA $^{a}$ & 13.0 & 10.0 & 12.2 & 10.8 & 10.8 & 8.2 & 9.0 & NI & NI & NI & & & 19.0 & \\
\hline C. albicans & 16.0 & 14.0 & 13.0 & 11.8 & 11.0 & 10.5 & 9.5 & 9.5 & NI & $\mathrm{NI}$ & & & & 23.0 \\
\hline C. neoformans & 19.0 & 14.0 & 18.0 & 13.0 & 15.0 & 11.0 & 11.5 & 9.0 & NI & NI & & & & 26.0 \\
\hline C. herbarum & 13.0 & 12.0 & 12.0 & 11.0 & NI & NI & NI & NI & NI & $\mathrm{NI}$ & & & & 23.0 \\
\hline M. canis & 33.0 & 19.0 & 32.0 & 18.0 & 24.0 & 12.5 & 17.5 & $\mathrm{NI}$ & NI & $\mathrm{NI}$ & & & & 22.0 \\
\hline T. rubrum & 24.0 & 16.0 & 22.0 & 14.0 & 16.5 & 10.0 & 12.5 & NI & NI & NI & & & & 20.0 \\
\hline
\end{tabular}

${ }^{a}$ methicilin resistant Staphylococcus aureus; NI: no inhibition; GE: Gentamicin; OX: Oxacilin; VA: Vancomycin; KT: Ketoconasol.

Table 3. Minimum inhibitory concentration of aerial parts essential oil from Poiretia bahiana against six microbial species

\begin{tabular}{lccccc}
\hline Microrganism & $\begin{array}{c}\text { Sample / } \\
\left(\mathrm{mg} \mathrm{mL}^{-1}\right)\end{array}$ & \multicolumn{4}{c}{ Controls / $\left(\mu \mathrm{g} \mathrm{mL}^{-1}\right)$} \\
\cline { 3 - 6 } & 9.1 & 1.00 & - & - & - \\
\hline E. coli & 18.1 & 1.00 & - & - & - \\
P. mirabilis & 36.3 & & 0.25 & - & - \\
S. aureus & 36.3 & & - & 0.50 & - \\
MRSA $^{\mathrm{a}}$ & 2.3 & & - & - & 0.13 \\
C. albicans & 2.3 & & - & - & 0.25 \\
C. neoformans & & & & &
\end{tabular}

${ }^{a}$ methicilin resistant Staphylococcus aureus. GE: Gentamicin; OX: Oxacilin; VA: Vancomycin; KT: Ketoconasol.

umbellulone, the major component of the Poiretia oils, interferes strongly with respiration, heartbeat, and blood circulation, causing death in laboratory animals. Its inhalation by guinea pigs irritated mucous membranes of eyes and nose and caused irregular respiration at times, but no failure of respiration. ${ }^{13}$ In the present work, the essential oil from aerial parts of $P$. bahiana displayed moderate toxicity against Artemia salina with an $\mathrm{LC}_{50}$ of $459.03 \mu \mathrm{g} \mathrm{mL}^{-1}$. This result suggests the necessity of more accurate toxicity evaluation of the essential oils obtained from this species.

Studies showed that California bay (Umbellularia californica) is used by wood rats (Neotoma fuscipes) for fumigation of nest-borne ectoparasites. ${ }^{14}$ Leaves of this plant significantly reduced survival of flea larvae to $26.4 \%$. The biocidal activity of this plant has been associated with its high content in umbellulone (39\%), which has been shown to be toxic when fed to laboratory mice. ${ }^{11}$ Therefore, the high content of umbellulone in aerial parts of P. bahiana might be responsible for its reputed effectiveness to kill fleas.

\section{Acknowledgments}

The authors are grateful to CNPq for fellowships to F. M. Araújo and N. F. Roque and to FAPESB for fellowships to L. C. Souza-Neta. This work was supported by grants from CNPq, FAPESB and FINEP.

\section{Supplementary Information}

Supplementary data are available free of charge at http://jbcs.sbq.org.br as PDF file.

\section{References}

1. Müller, C.; MSc Dissertation, Universidade Estadual de Campinas, Brasil, 1984.

2. Information obtained by the authors from the local people.

3. Adams, R. P.; Identification of Essential Oil Components by Gas Chromatography/Quadrupole Mass Spectroscopy, Allured Publishing Corp: Carol Stream, IL, USA, 2001.

4. Joulain, D.; Köning, W. A.; The Atlas of Spectral Data of Sesquiterpene Hydrocarbons, E.B.-Verlag: Hamburg, Germany, 1998.

5. De Cerqueira, M. D.; Souza-Neta, L. C.; Passos, M. G. V. M.; Lima, E. O.; Roque, N. F.; Martins, D.; Guedes, M. L. S.; Cruz, F. G.; J. Braz. Chem. Soc. 2007, 18, 998.

6. Rios, J. L.; Recio, M. C.; Villar, A.; J. Ethnopharmacol. 1988, 23, 127. 
7. Alves, T. M. A.; Silva, A. F.; Brandão, M.; Grandi, T. S. M.; Smânia, E. F. A.; Junior, A. S.; Zani, C. L.; Mem. Inst. Oswaldo Cruz 2000, 95, 367.

8. Meyer, B. N.; Ferrigini, N.; Putnam, J. E.; Jacobsen, L. B.; Nichols, D. E.; McLaughlin, J. L.; Planta Med. 1982, 45, 31.

9. Janssen, A. M.; Scheffer, J. J. C.; Svendsen, A. B.; Planta Med. 1987, 53, 395.

10. Hili, P.; Evans, C. S.; Veness, R. G.; Lett. Appl. Microbiol. 1997, 24, 269.
11. MacGregor, J. T.; Layton, L. L.; Buttery, R. G.; J. Agric. Food Chem. 1974, 22, 777.

12. Squeo, R. F.; Beer, R.; Silvers, D.; Weitzman, I.; Grossman, M.; J. Am. Acad. Dermatol. 1998, 39, 379.

13. Drake, M. E.; Stuhr, E. T.; J. Am. Pharm. Assoc. 1935, 24, 196.

14. Hemmes, R. B.; Alvarado, A.; Hartb, B. L.; Behav. Ecol. 2002, 13,381 .

Received: April 23, 2008

Web Release Date: October 16, 2009 


\section{Composition and Antimicrobial Activity of Essential Oils from Poiretia bahiana C. Müller (Papilionoideae-Leguminosae)}

Floricéa M. Araújo, ${ }^{a}$ Maria das Graças V. M. Passos, ${ }^{b}$ Edeltrudes de O. Lima, ${ }^{c}$ Nídia F. Roque, ${ }^{a}$ Maria L. S. Guedes, ${ }^{d}$ Lourdes C. de Souza-Neta, ${ }^{a}$ Frederico Guaré Cruz ${ }^{*, a}$ and Dirceu Martins ${ }^{a}$

aInstituto de Química, ${ }^{b}$ Faculdade de Farmácia and ${ }^{d}$ Instituto de Biologia,

Universidade Federal da Bahia, Campus de Ondina, 40190-270 Salvador-BA, Brazil

${ }^{c}$ Centro de Ciências da Saúde, Universidade Federal da Paraíba, 58059-900 João Pessoa-PB, Brazil

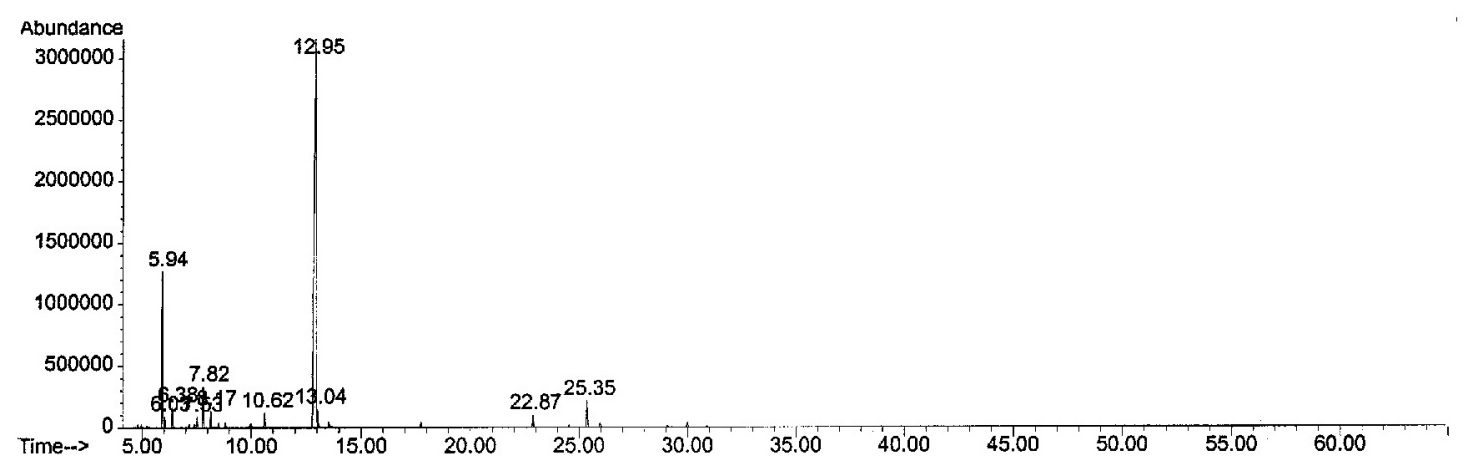

Figure S1. Total ion chromatogram of MPIFI[GC/MS ; EI $70 \mathrm{eV}]$.

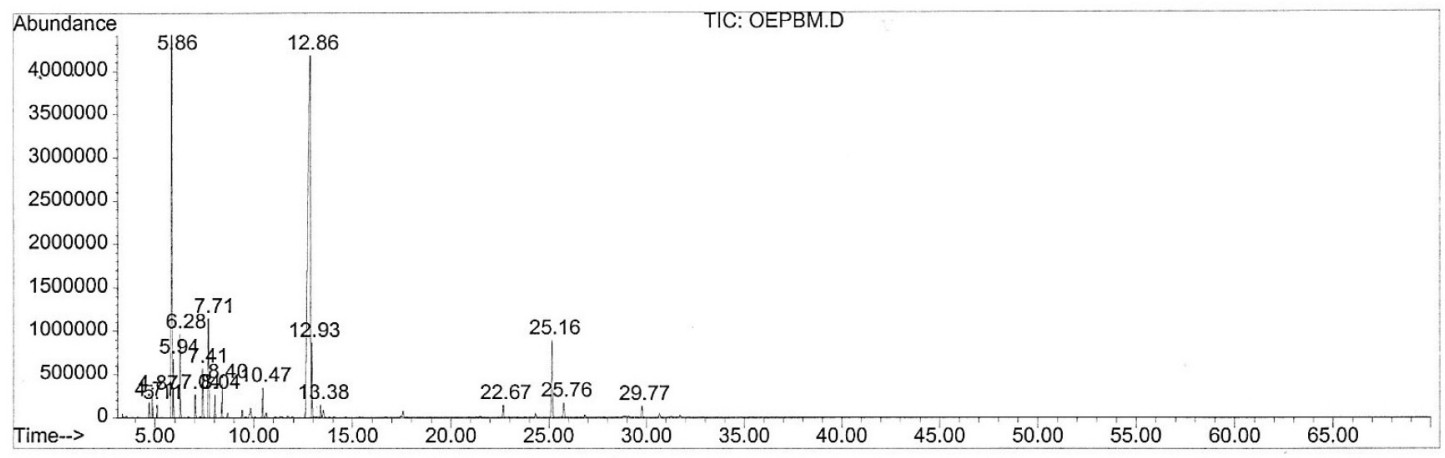

Figure S2. Total ion chromatogram of MFl [GC/MS ; EI $70 \mathrm{eV}]$. 


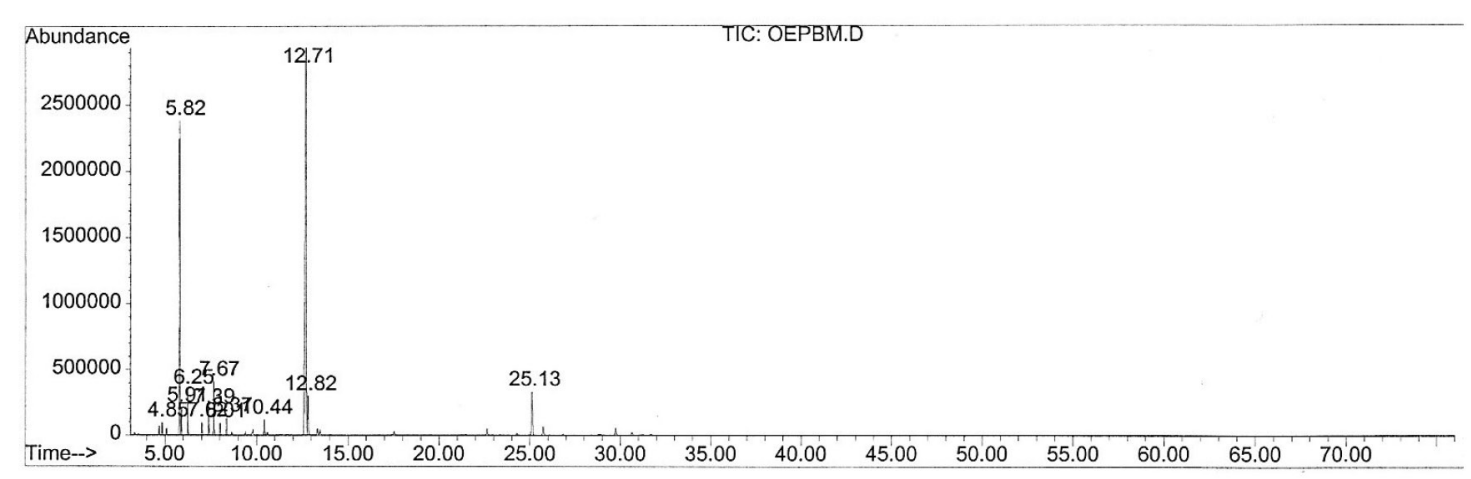

Figure S3. Total ion chromatogram of CFI [GC/MS ; EI $70 \mathrm{eV}]$.

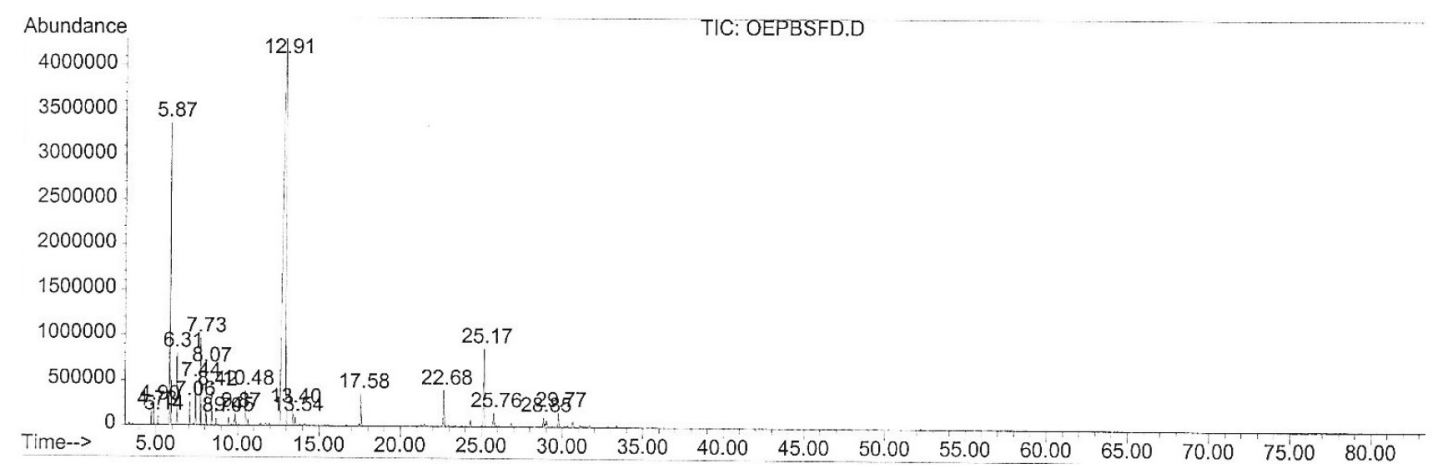

Figure S4. Total ion chromatogram of MWFl [GC/MS ; EI $70 \mathrm{eV}]$.

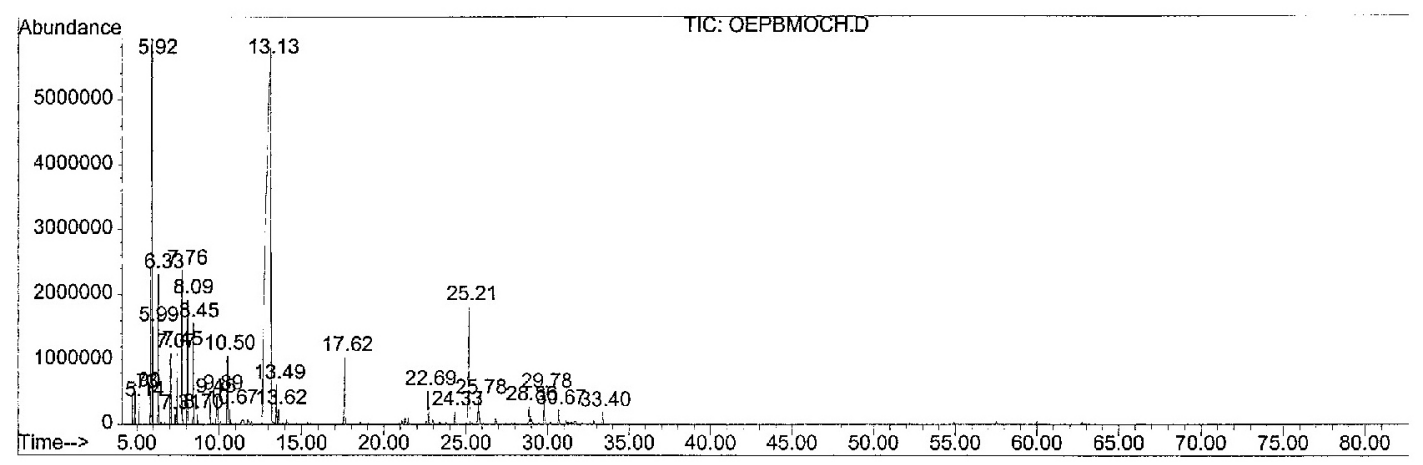

Figure S5. Total ion chromatogram of MCWFI [GC/MS ; EI $70 \mathrm{eV}]$. 


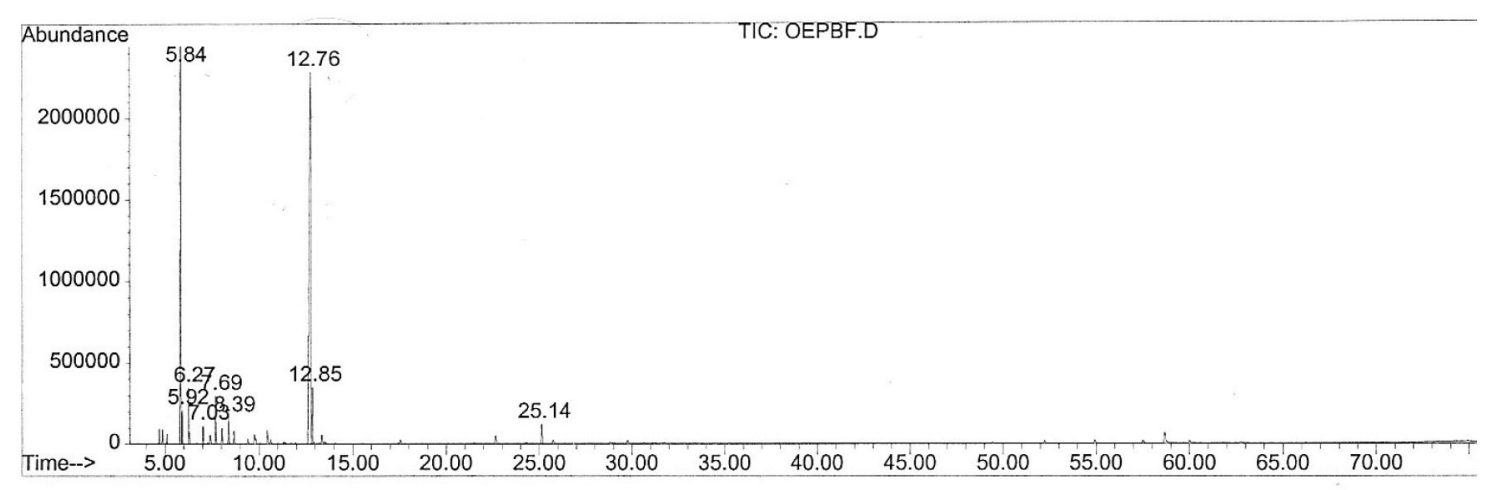

Figure S6. Total ion chromatogram of CFr [GC/ME ; EI $70 \mathrm{eV}$ ].

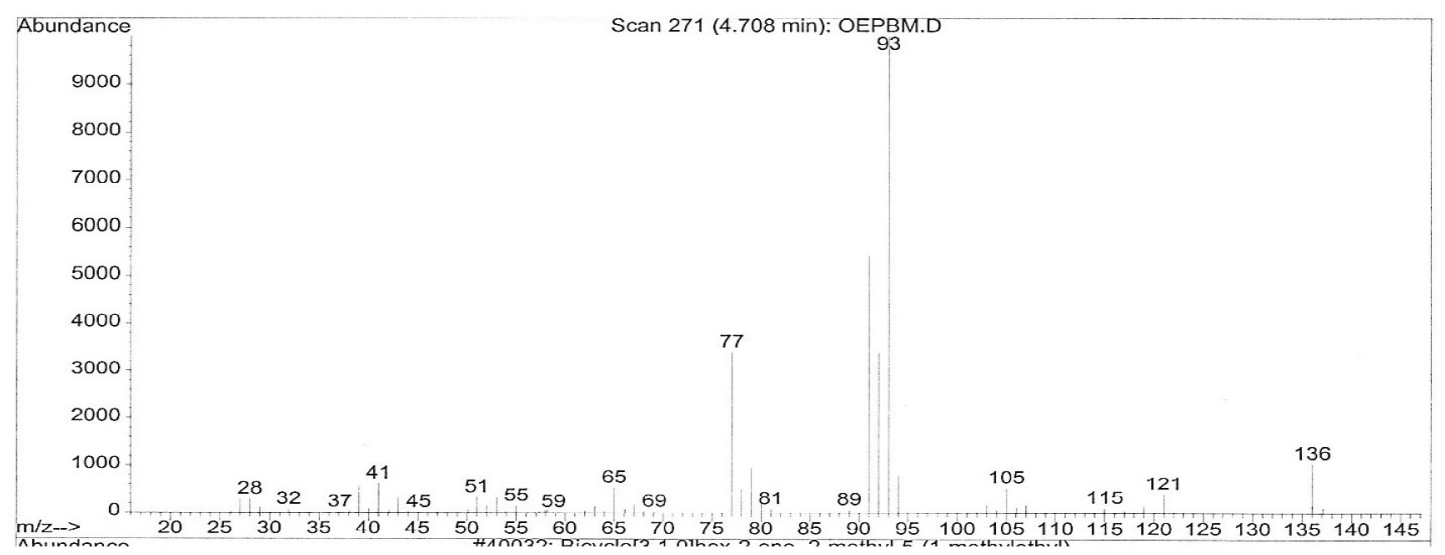

Figure S7. Mass spectrum of $\alpha$ - thujene [EI, $70 \mathrm{eV}$ ].

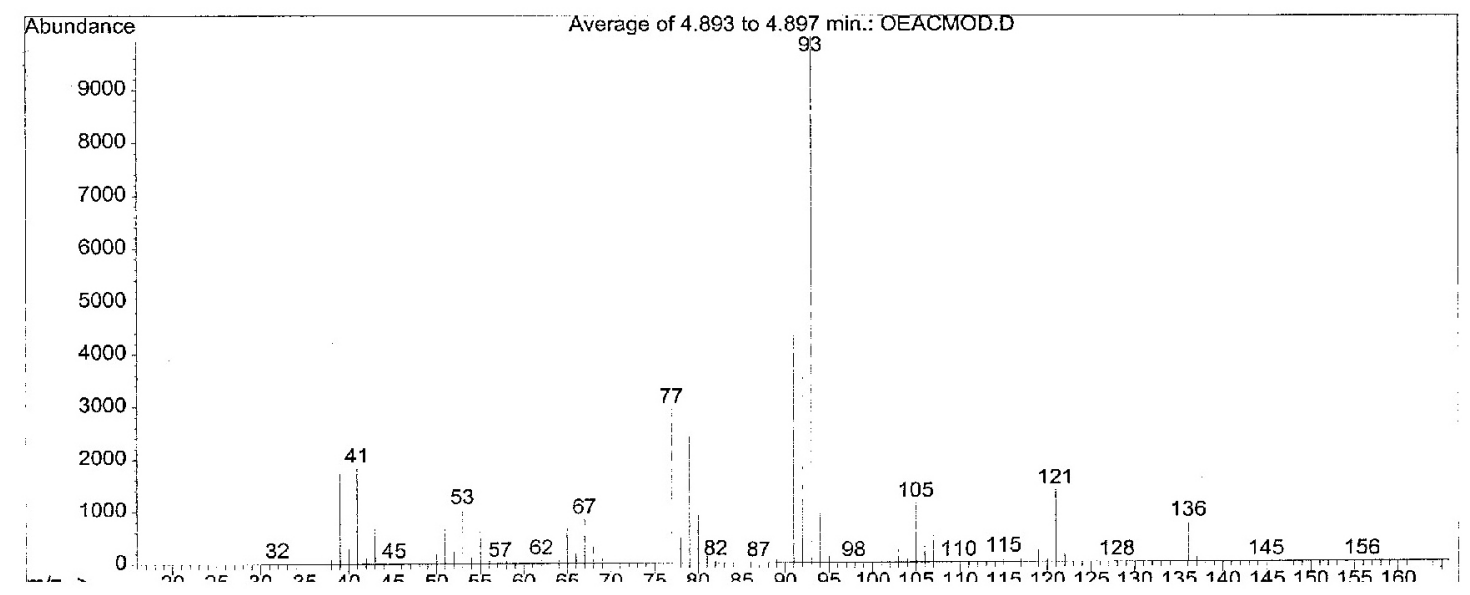

Figure S8. Mass spectrum of $\alpha$-pinene [EI, $70 \mathrm{eV}]$. 


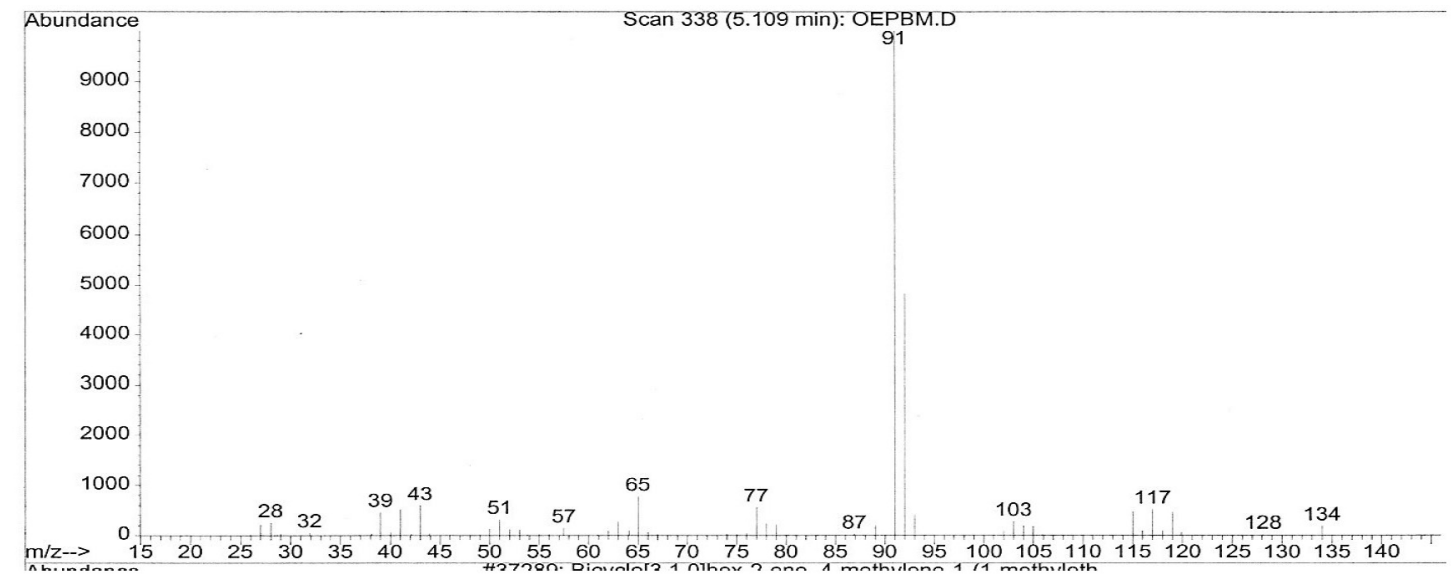

Figure S9. Mass spectrum of thuja-2.4(10)-diene [EI, $70 \mathrm{eV}]$.

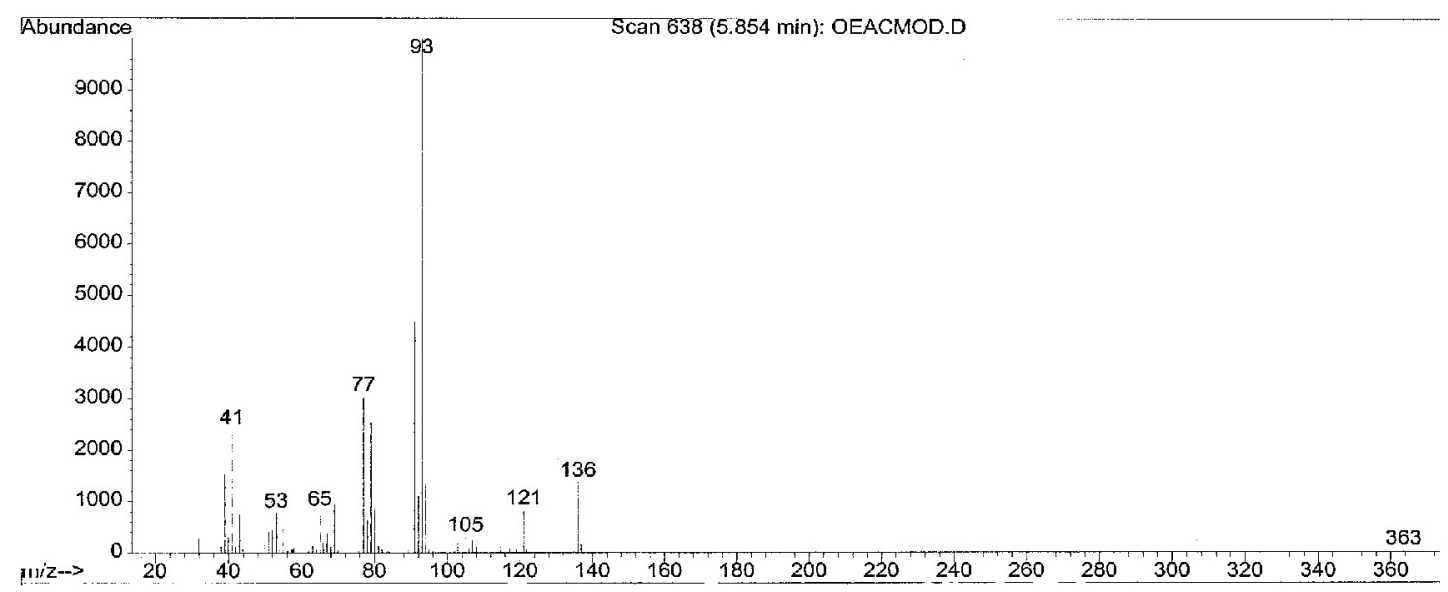

Figure S10. Mass spectrum of sabinene [EI, $70 \mathrm{eV}]$.

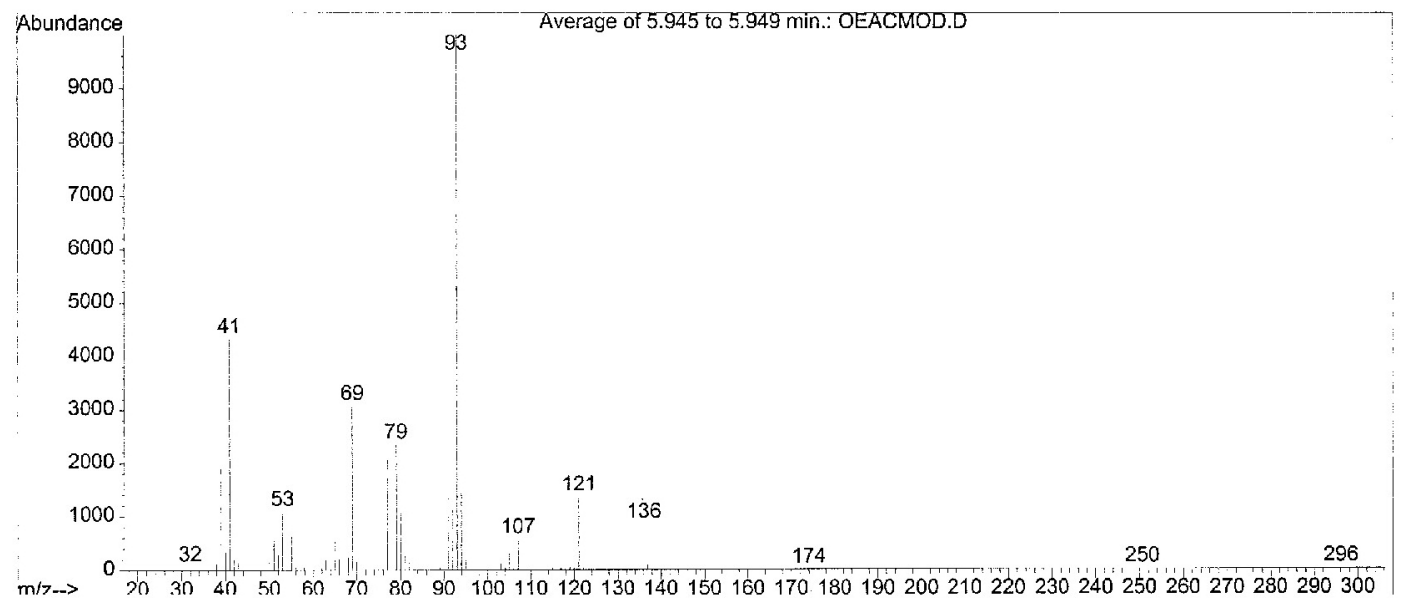

Figure S11. Mass spectrum of $\beta$-pinene [EI, $70 \mathrm{eV}]$. 


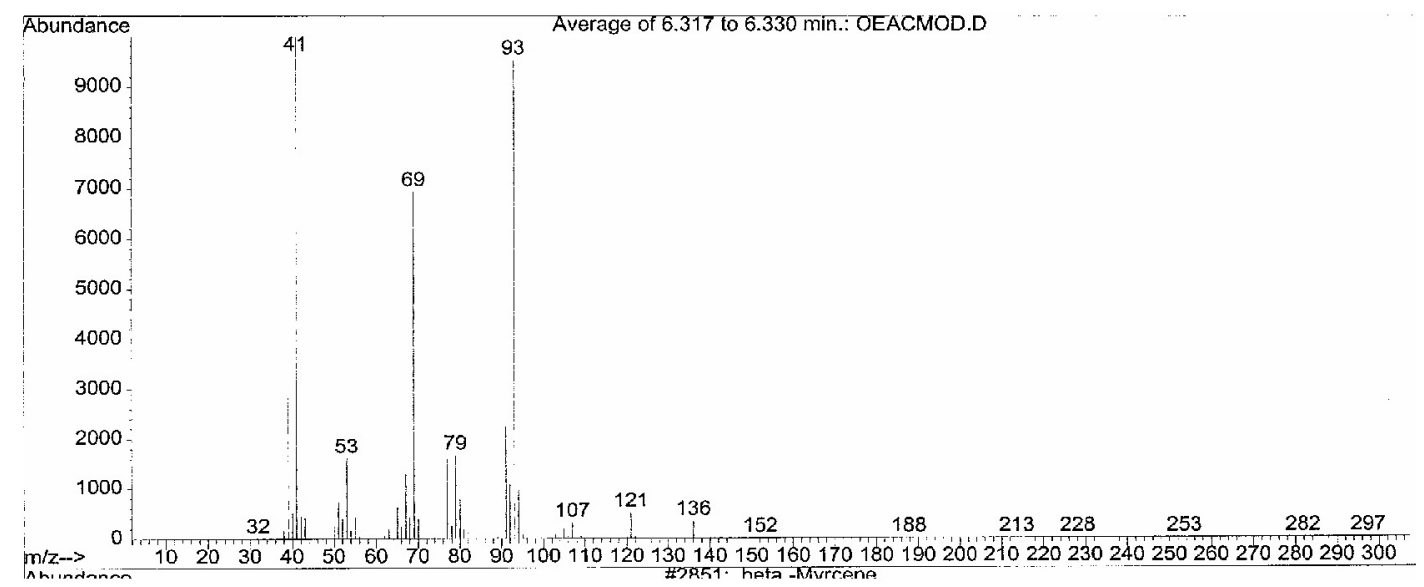

Figure S12. Mass spectrum of myrcene [EI, $70 \mathrm{eV}]$.

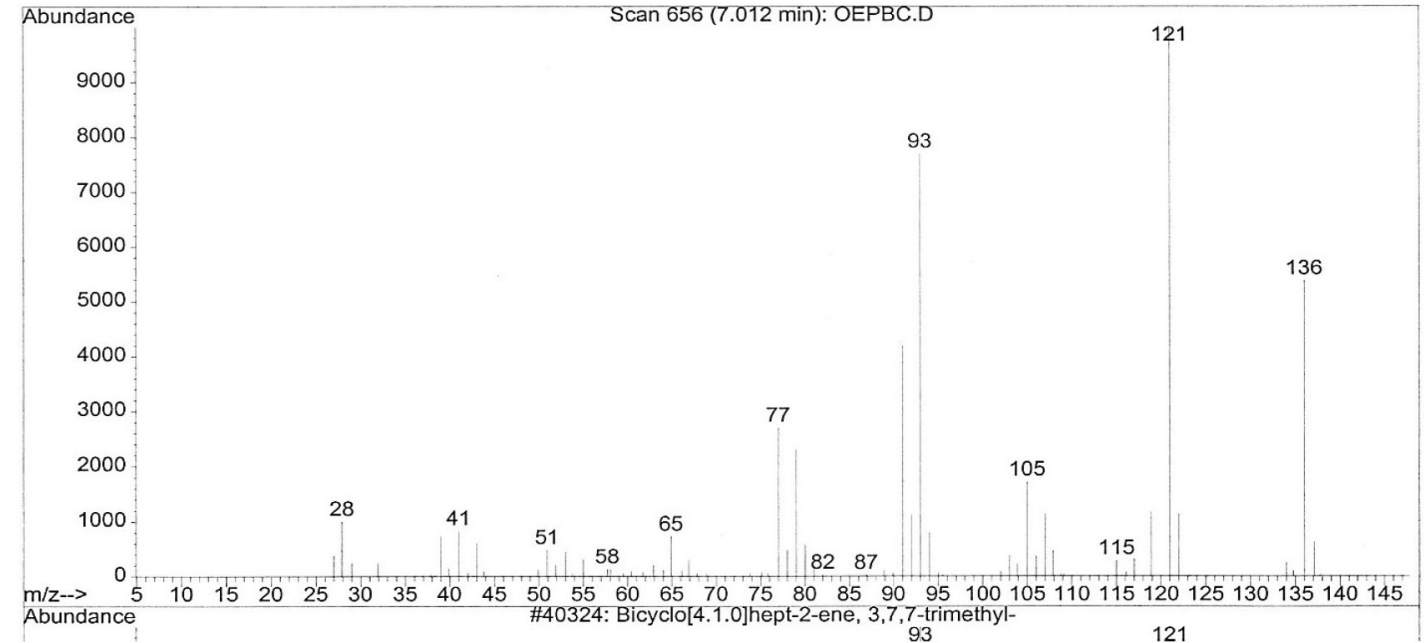

Figure S13. Mass spectrum of $\alpha$-terpinene [IE, $70 \mathrm{eV}$ ].

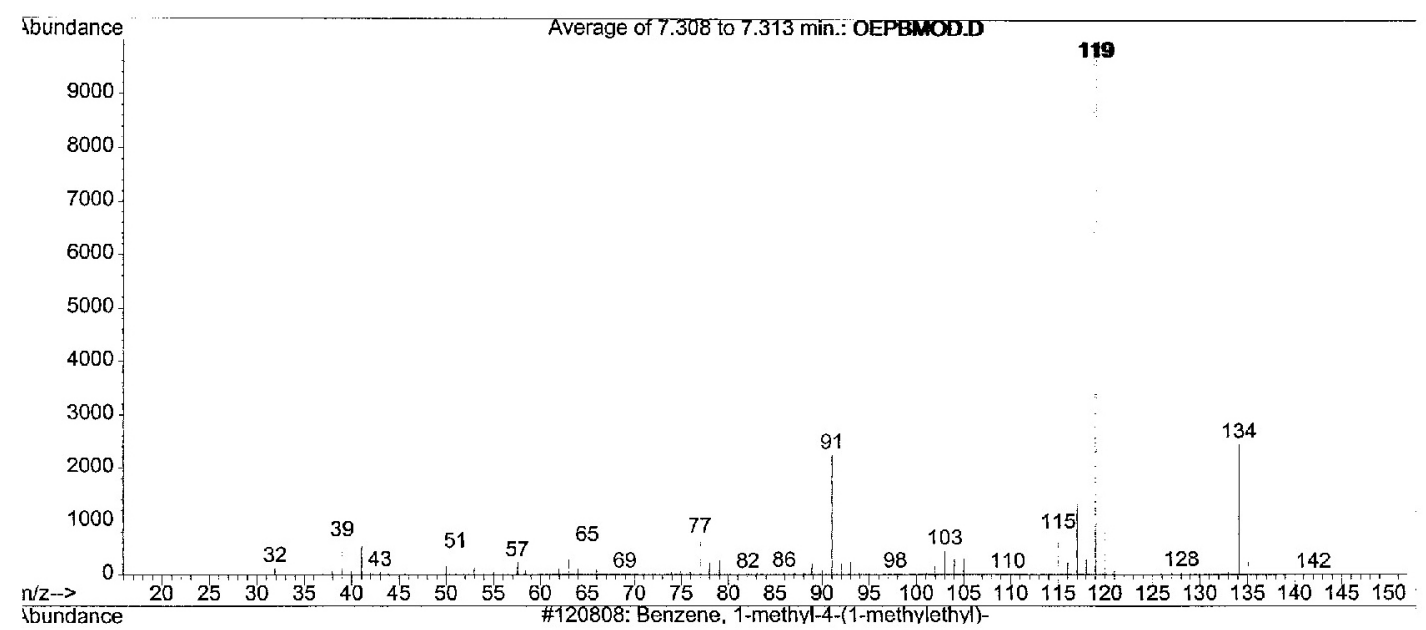

Figure S14. Mass spectrum of o-cymene [EI, $70 \mathrm{eV}]$. 


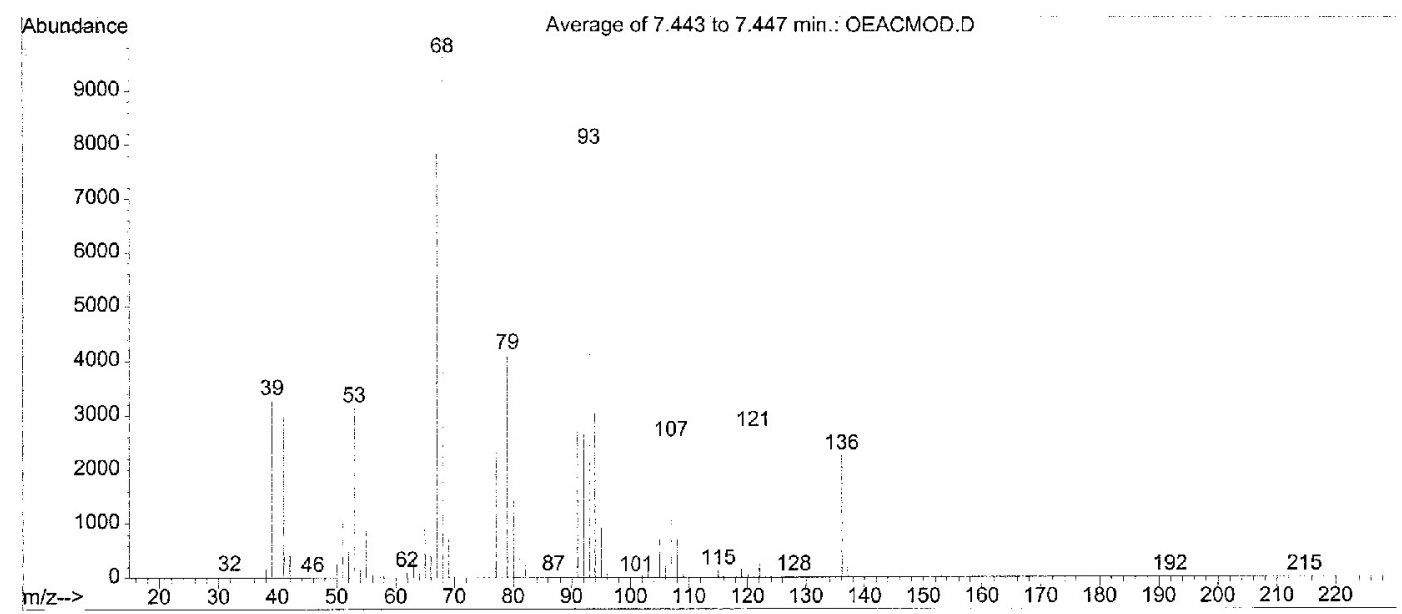

Figure S15. Mass spectrum of limonene [EI, $70 \mathrm{eV}]$.

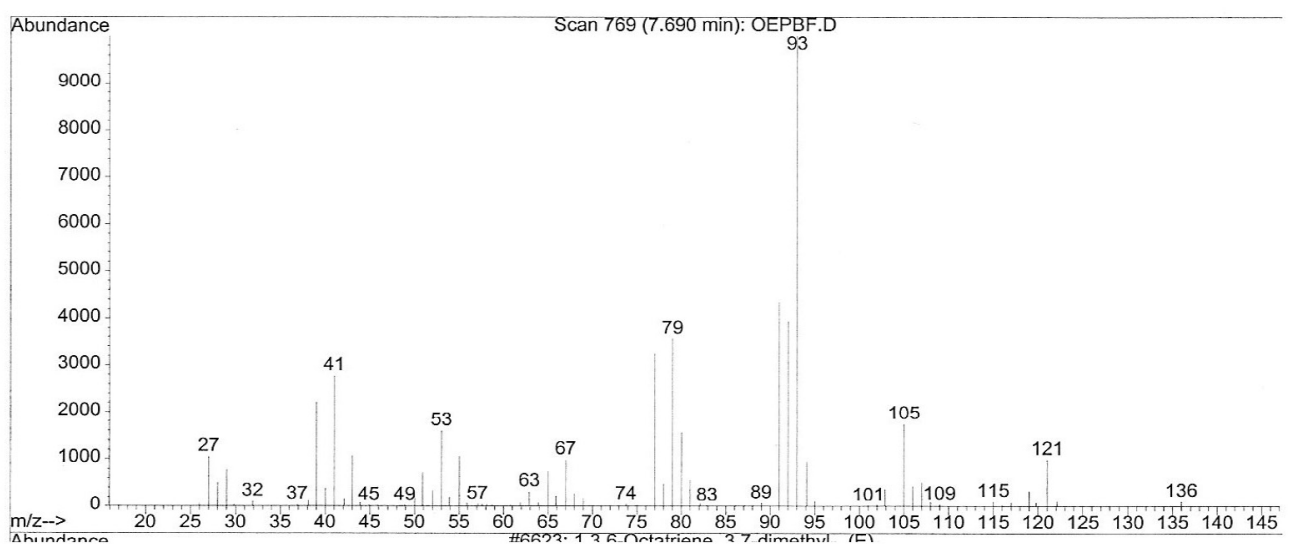

Figure S16. Mass spectrum of (Z)-ocimene [IE, $70 \mathrm{eV}]$.

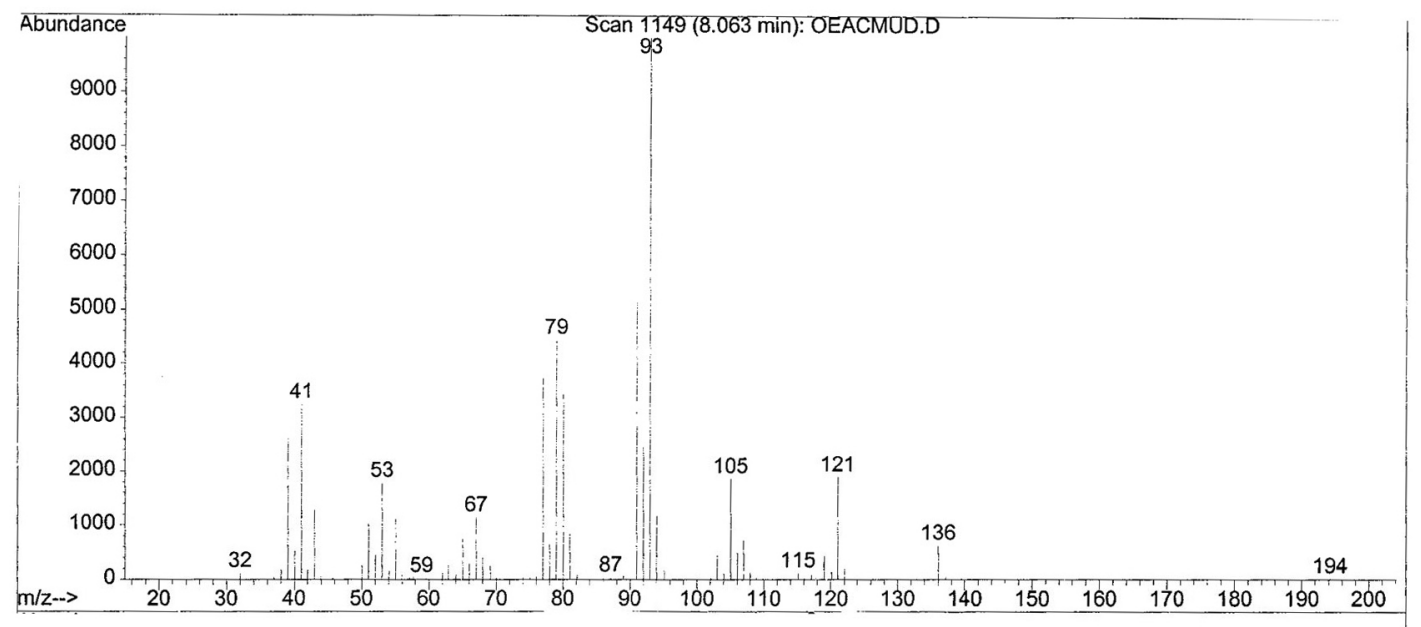

Figure S17. Mass spectrum of (E)-ocimene [EI, $70 \mathrm{eV}]$. 


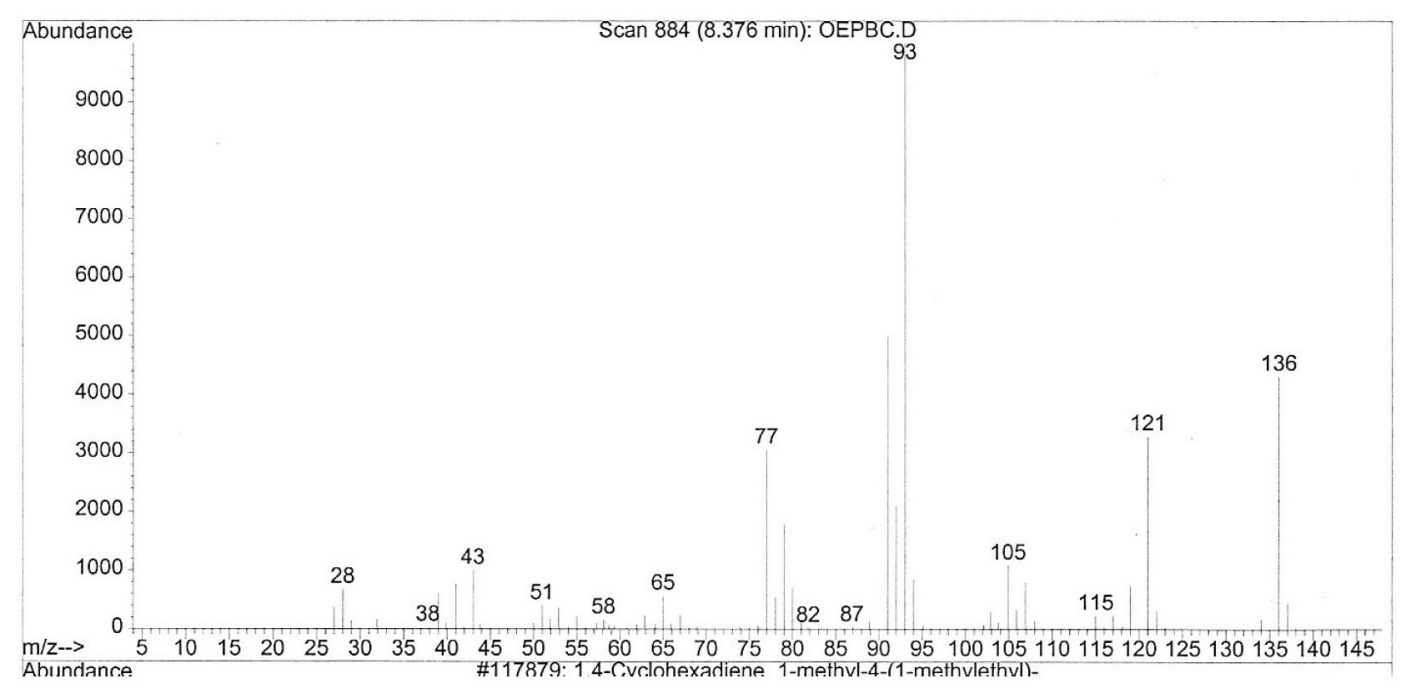

Figure S18. Mass spectrum of $\gamma$-terpinene [IE, $70 \mathrm{eV}]$.

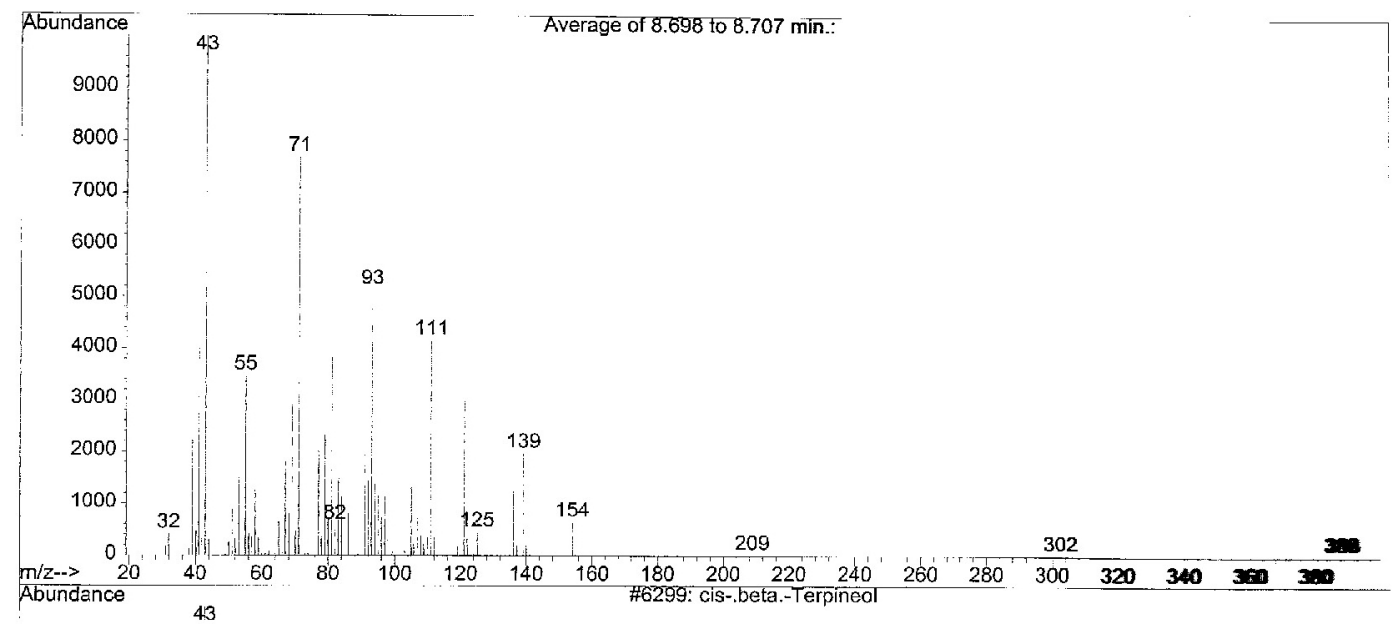

Figure S19. Mass spectrum of cis-hydrate sabinene [IE, $70 \mathrm{eV}$ ].

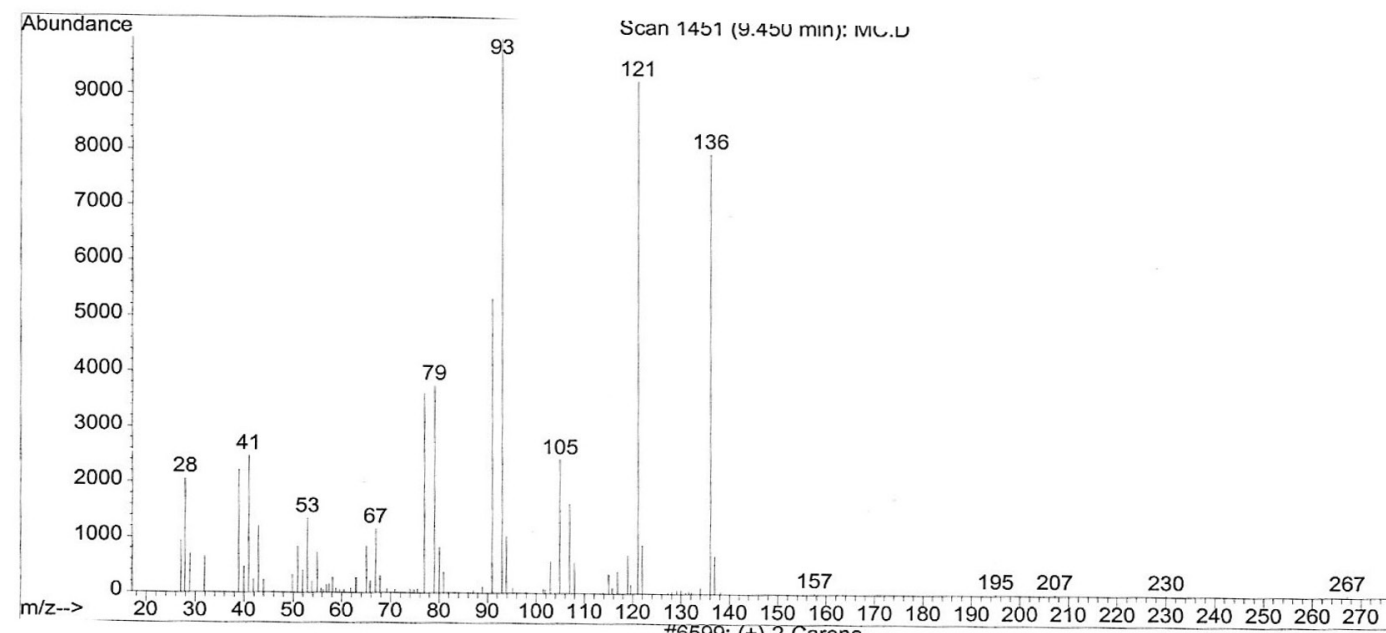

Figure S20. Mass spectrum of terpinolene [IE, $70 \mathrm{eV}]$. 


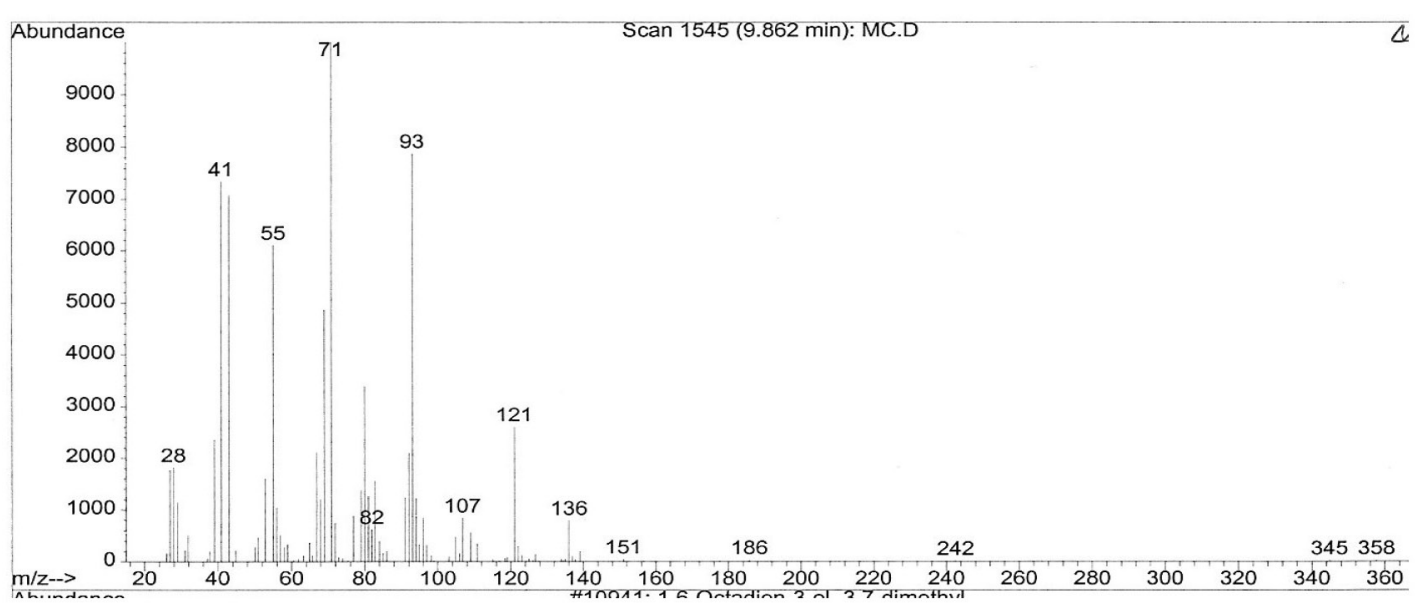

Figure S21. Mass spectrum of linalool [IE, $70 \mathrm{eV}]$.

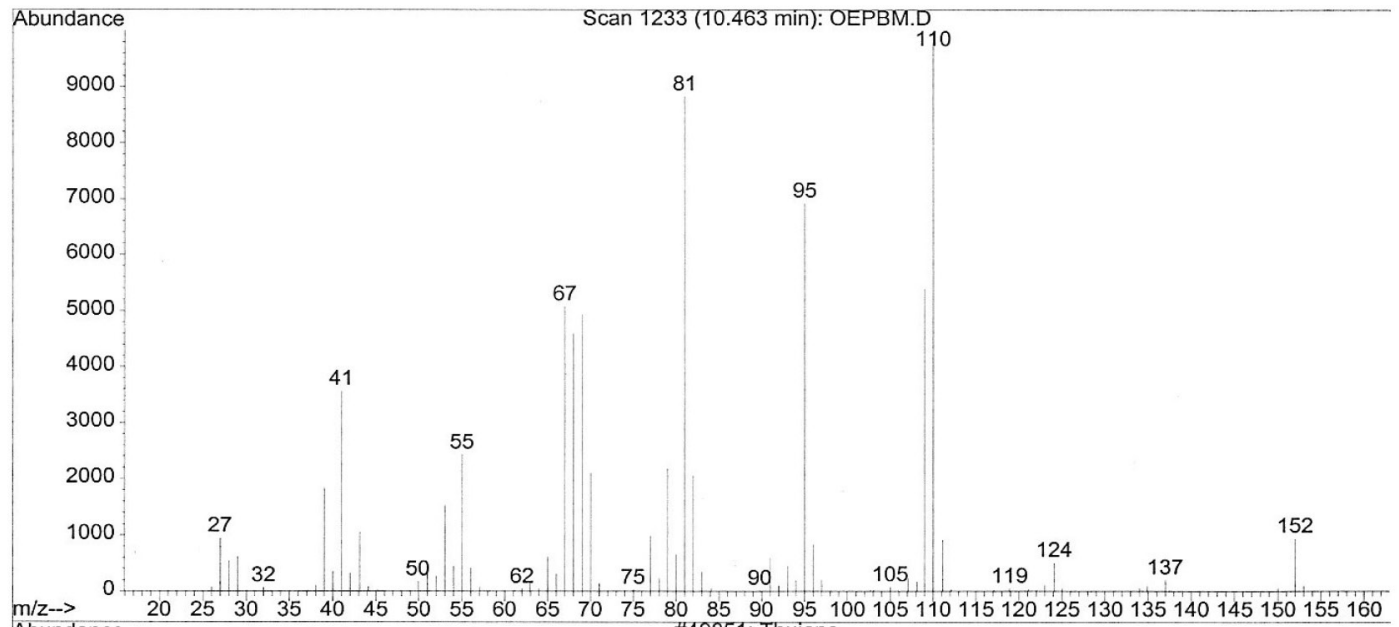

Figure S22. Mass spectrum of thujone [IE, $70 \mathrm{eV}]$.

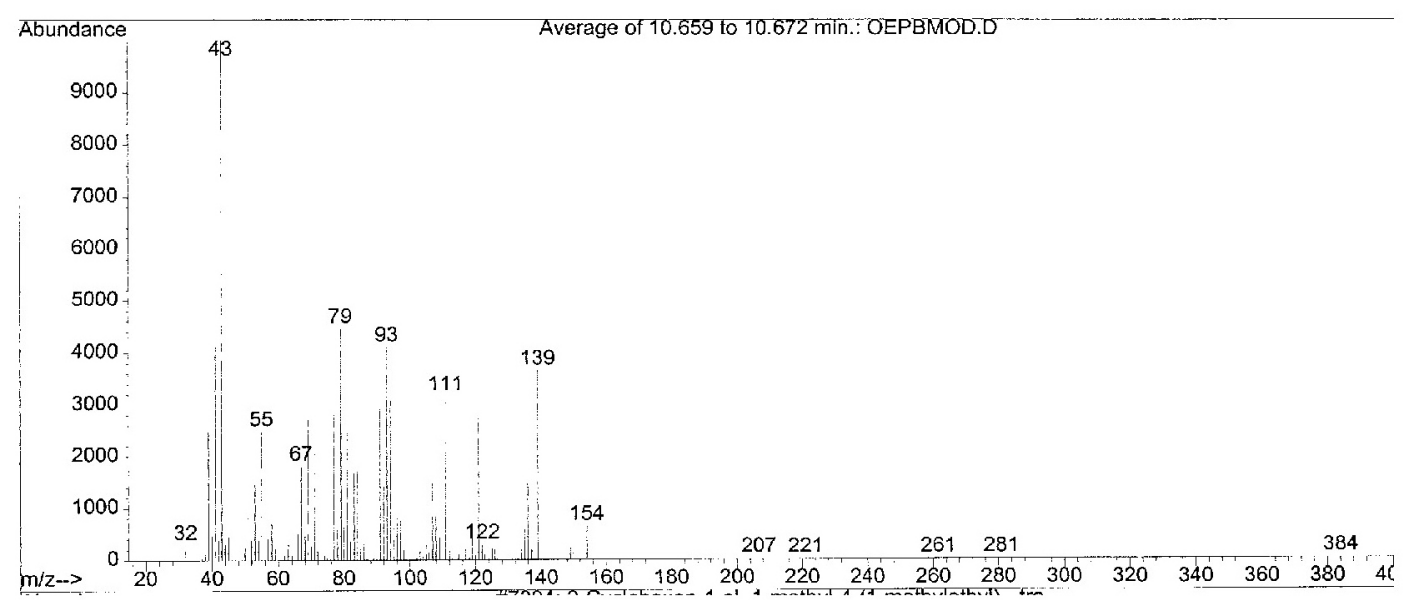

Figure S23. Mass spectrum of p-menth-2-en-1-ol [IE, $70 \mathrm{eV}]$. 


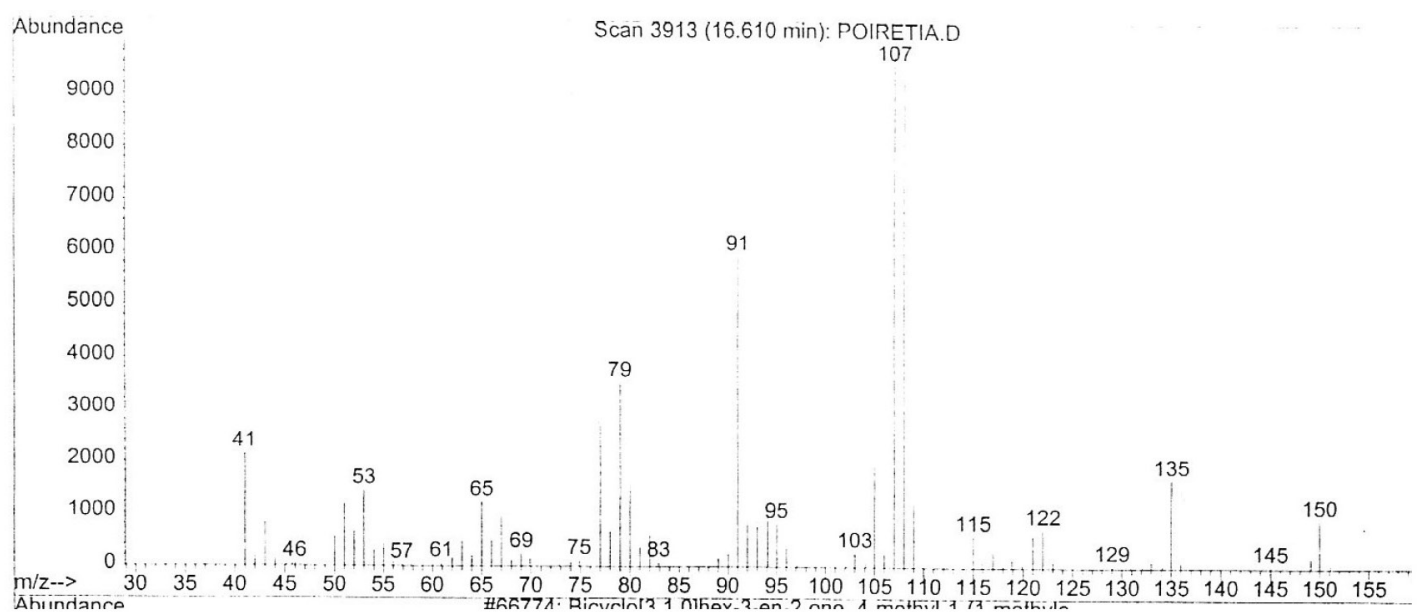

Figure S24. Mass spectrum of umbellulone [IE, $70 \mathrm{eV}]$.

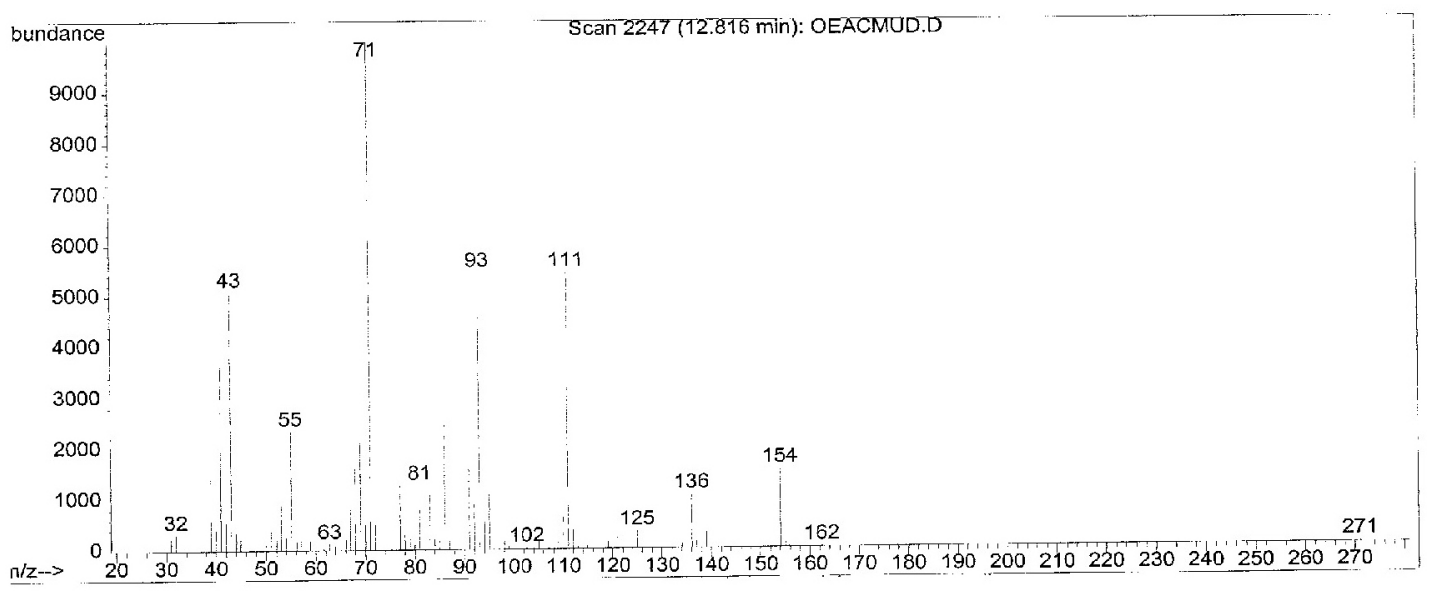

Figure S25. Mass spectrum of terpinen-4-ol [EI, $70 \mathrm{eV}$ ].

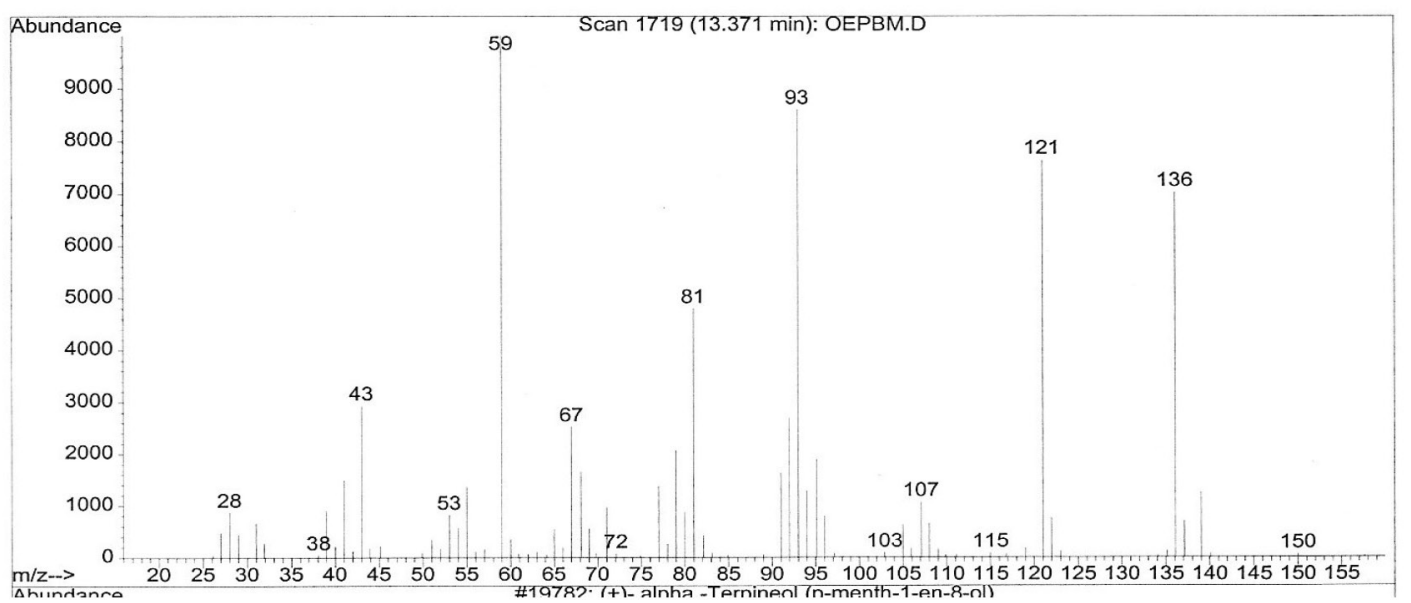

Figure S26. Mass spectrum of $\alpha$-terpineol [IE, $70 \mathrm{eV}]$. 


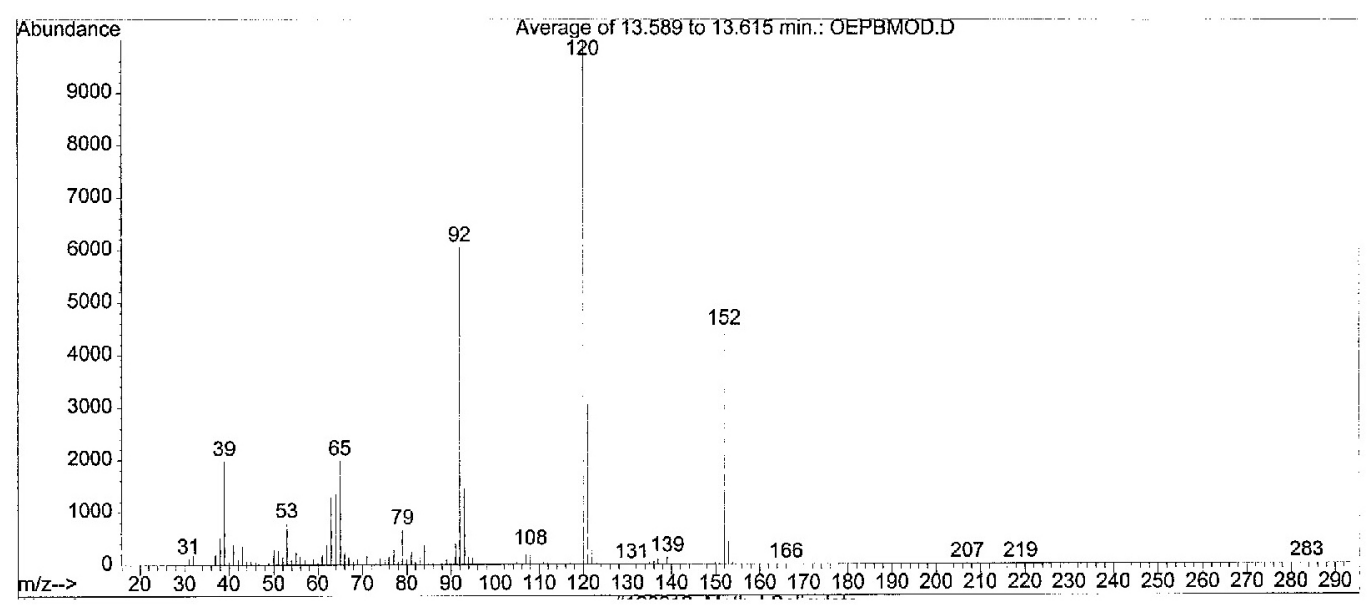

Figure S27. Mass spectrum of methyl salicylate [IE, $70 \mathrm{eV}$ ].

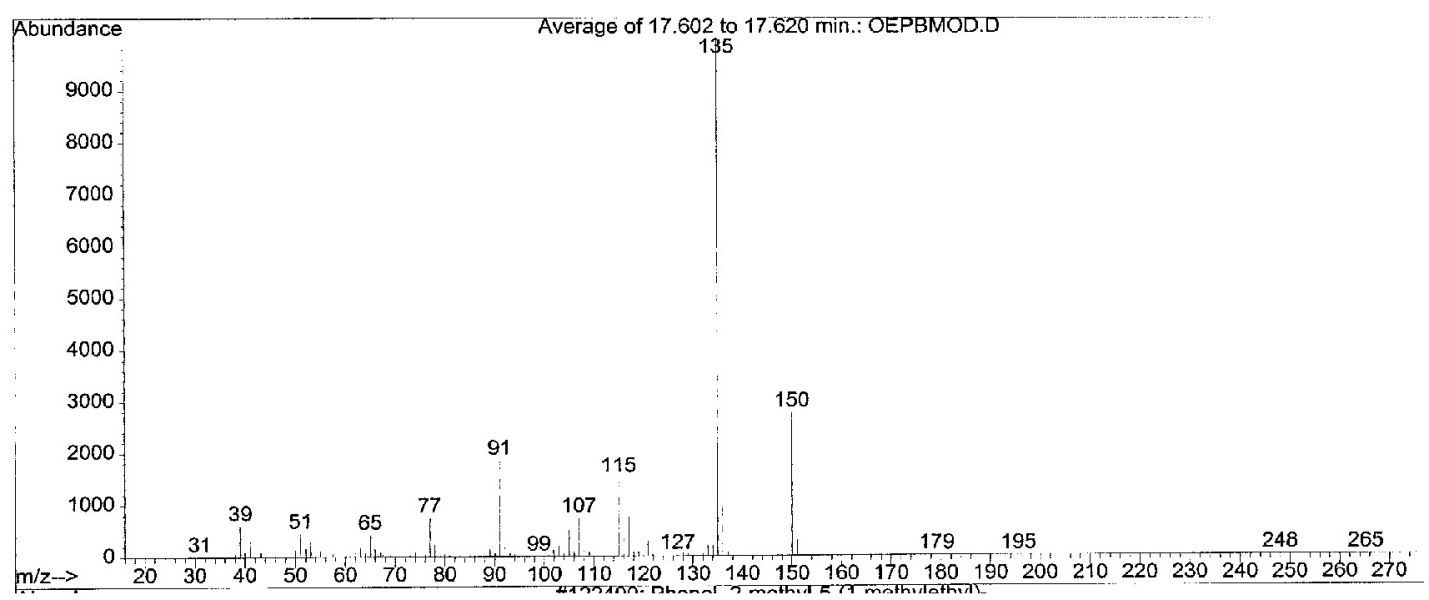

Figure S28. Mass spectrum of thymol [IE, $70 \mathrm{eV}]$.

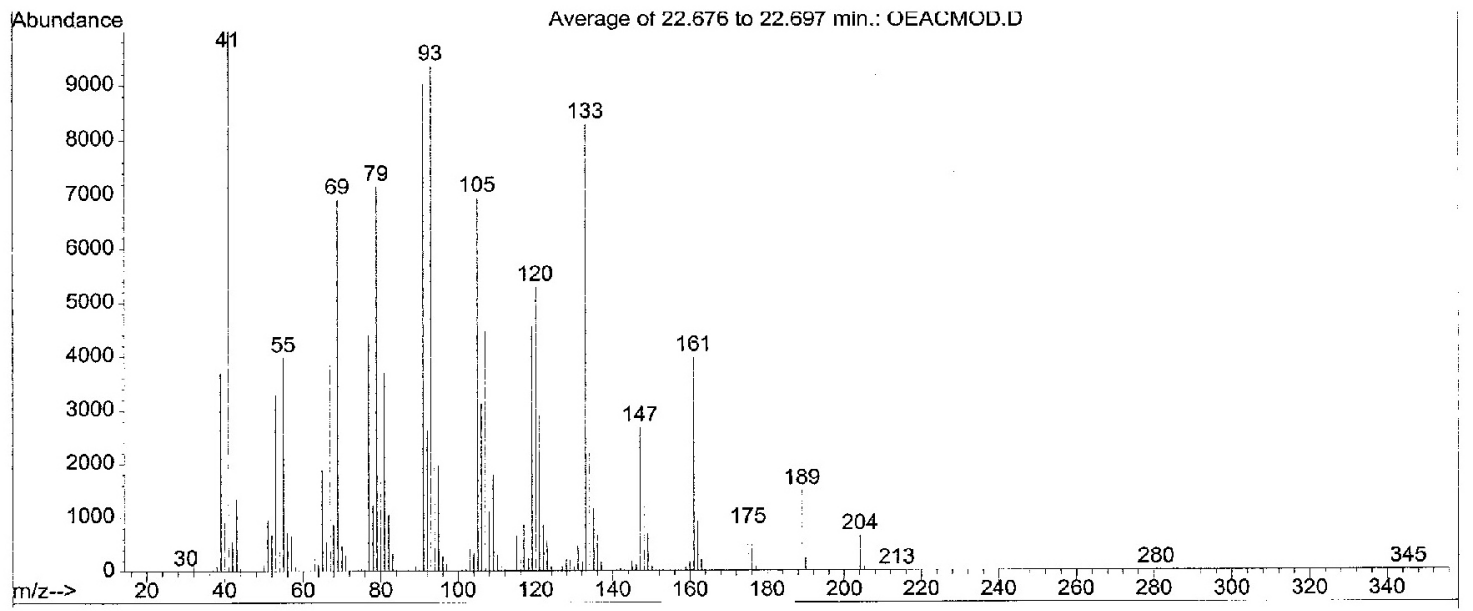

Figure S29. Mass spectrum of $E$-caryophyillene [EI, $70 \mathrm{eV}$ ]. 


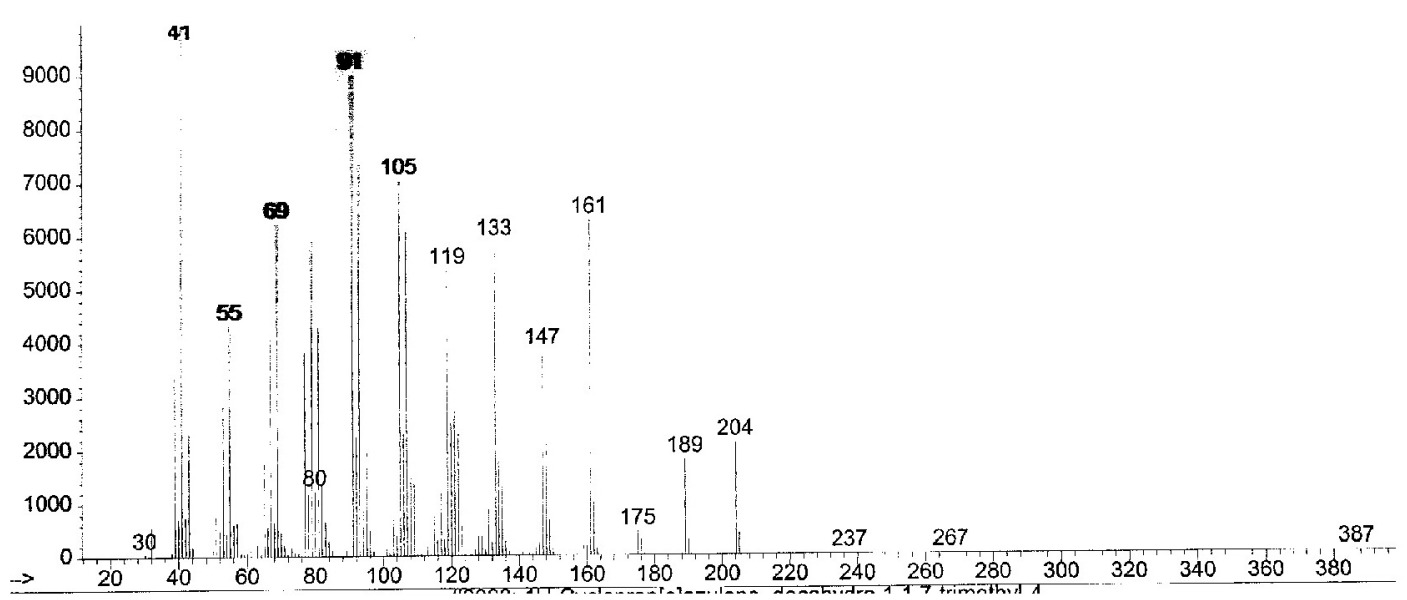

Figure S30. Mass spectrum of allo-aromadendrene [IE, $70 \mathrm{eV}]$.

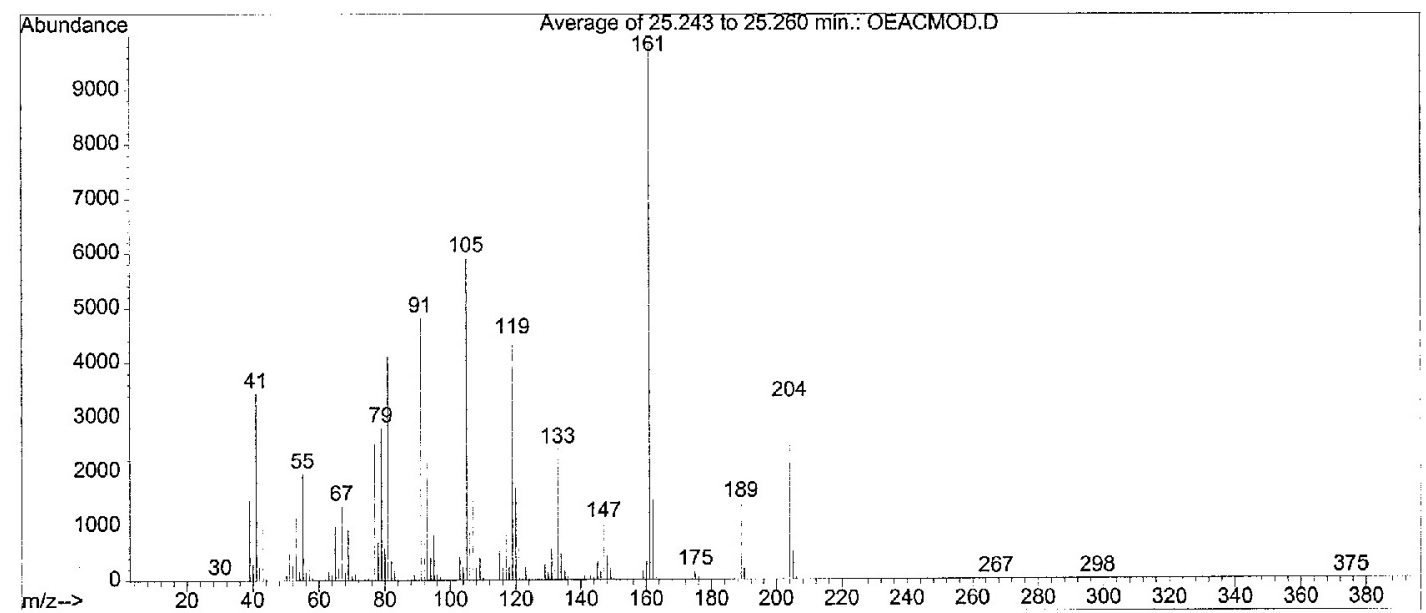

Figure S31. Mass spectrum of germacrene-D [EI, $70 \mathrm{eV}]$.

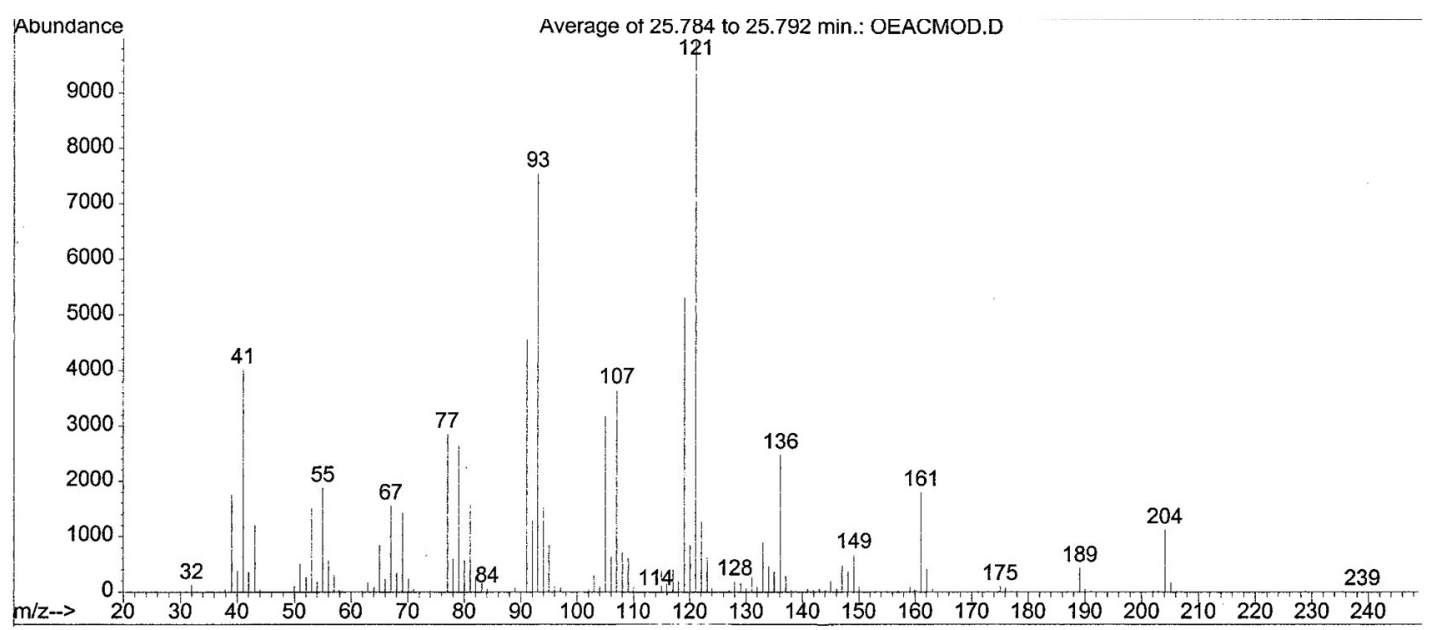

Figure S32. Mass spectrum of biciclogermacrene [EI, $70 \mathrm{eV}]$. 


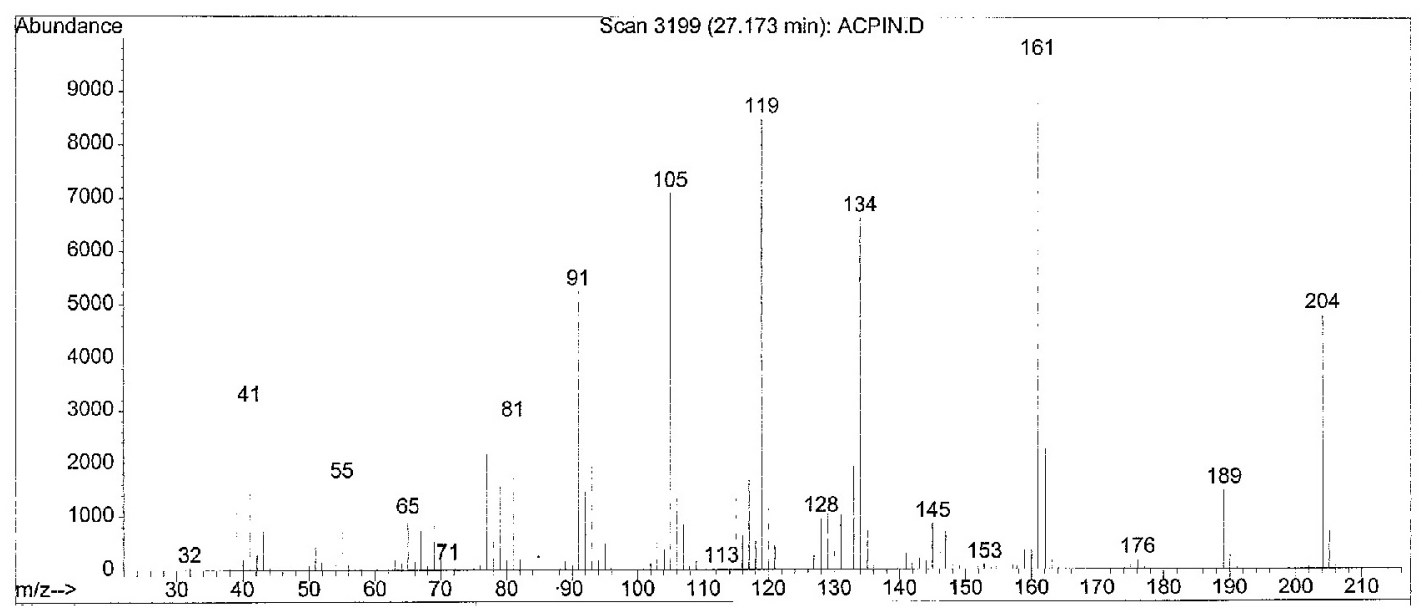

Figure S33. Mass spectrum of $\delta$-cadinene [EI, $70 \mathrm{eV}]$.

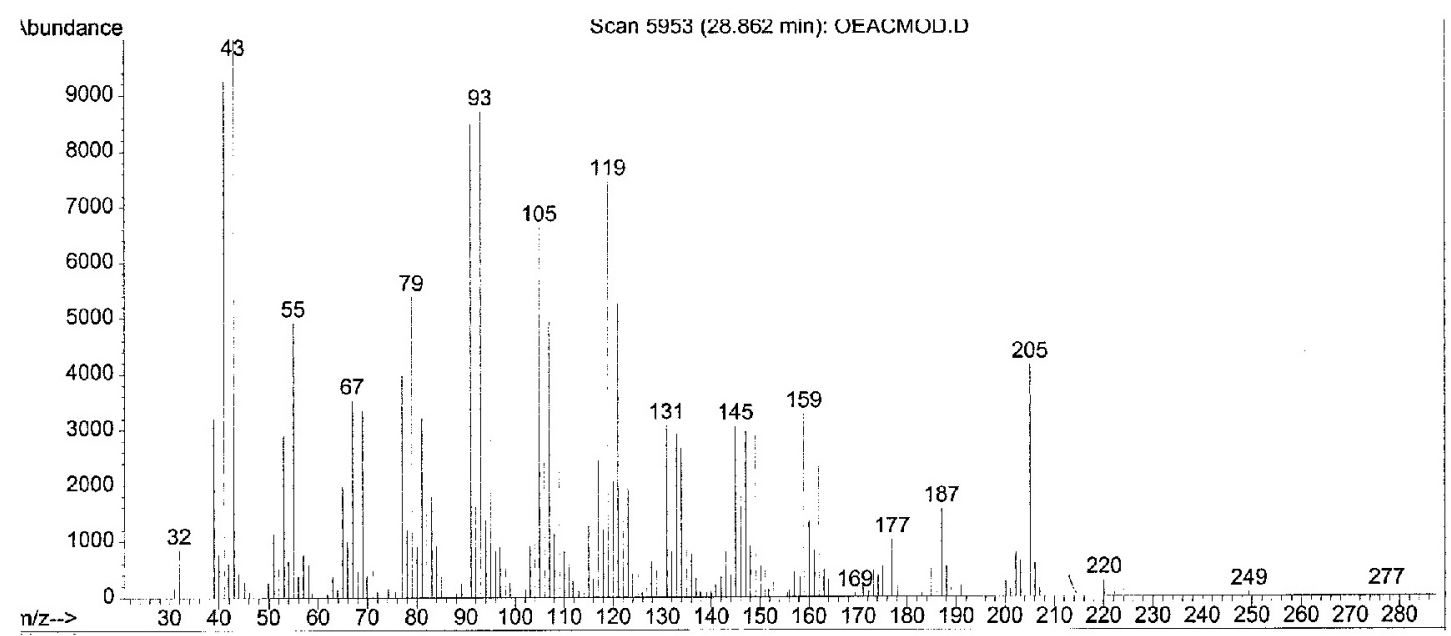

Figure S34. Mass spectrum of spathulenol [EI, $70 \mathrm{eV}$ ].

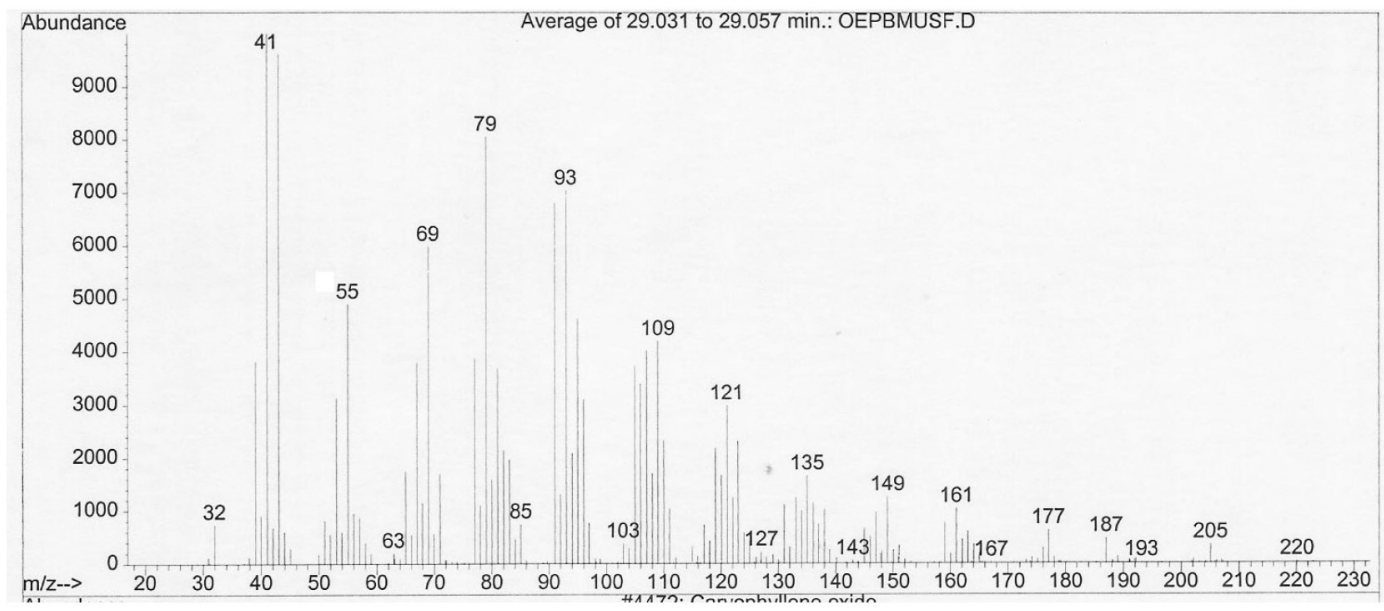

Figure S35. Mass spectrum of caryophyllene oxide [EI, $70 \mathrm{eV}]$. 